Nat. Hazards Earth Syst. Sci. Discuss., https://doi.org/10.5194/nhess-2017-435

Manuscript under review for journal Nat. Hazards Earth Syst. Sci.

Discussion started: 15 January 2018

(c) Author(s) 2018. CC BY 4.0 License.

\title{
Seismic vulnerability of vernacular Newari buildings in Nepal: observations and analysis of damage due to 1934, 1988, 2011, and 2015 earthquakes
}

\author{
Dipendra Gautam ${ }^{1,2}$, Hugo Rodrigues ${ }^{3}$
}

$5 \quad{ }^{1}$ Structural and Earthquake Engineering Research Institute (SERI), Kathmandu, Nepal

${ }^{2}$ School of Engineering, Pokhara University, Kaski, Nepal

3 RISCO, School of Technology and Management, Polytechnic Institute of Leiria, Leiria, Portugal

Correspondence to: Dipendra Gautam (dipendra.gautam.seri@gmail.com)

Abstract. This paper reports the seismic vulnerability of vernacular Newari buildings based on the damage observations during

10 four major earthquakes $(1934,1988,2011$ and 2015) that struck Bhaktapur city. Some specific features that contributed to collapse prevention in traditional masonry buildings are also highlighted in this paper. In this paper, we have outlined the insights of each earthquake using forensic interpretations and the recommendations by various researchers after 1934 and 1988 earthquakes are compared in terms of their implementation. With the help of damage database recorded during 1934, 1988 and 2015 earthquakes, we have created damage probability matrices and empirical fragility functions for traditional masonry

15 structures. The fragility functions and damage probability matrices derived in this study highlight that most of the vernacular Newari buildings are likely to be collapsed in the case of strong to major earthquakes.

\section{Background}

Since the recorded history of earthquakes in Nepal that affected Kathmandu valley; Bhaktapur city has been identified as the area that sustains severer damage than other neighboring towns. As systematic records of earthquake damage are available since the $19^{\text {th }}$ century only, little is known about the devastating earthquakes historical earthquakes until $18^{\text {th }}$ century. To this end, the available record of 1833 earthquake $\left(\mathrm{M}_{\mathrm{L}}\right.$ 7.7) can be considered as the more detailed one although it is not exhaustive. Bilham (1995) reported that 410 fatalities and more than 4000 buildings were recorded to be damaged in Kathmandu valley alone due to the 1833 earthquake. Following the 1833 earthquake, notable seismic events from 1834, 1917, 1934, 1936, 1938, 1952, 1953, 1954, 1958, 1959, 1962, 1964, 1966, 1970, 1972, 1973, 1974, 1984, 1986, 1987, 1988, 2007, 2011, 2014 and 2015

25 have affected Kathmandu valley (Rana, 1935; Gupta, 1988; Fujiwara et al., 1989); however, accounts of building damage are available for 1934, 1988, 2011 and 2015 earthquakes only. Recently, a magnitude 7.8 earthquake struck central on 25 April 2015. Together with notable aftershocks of 25 April 2015, 26 April 2015 and 12 May 2015, Gorkha earthquake destroyed 1498852 buildings whereas other 256697 buildings were partly damaged (NPC, 2015). Consistently, Bhaktapur was the most affected town in Kathmandu valley during 2015 Gorkha earthquake. Bhaktapur is one of the oldest (13 ${ }^{\text {th }}$ century) town in 
Nat. Hazards Earth Syst. Sci. Discuss., https://doi.org/10.5194/nhess-2017-435

Manuscript under review for journal Nat. Hazards Earth Syst. Sci.

Discussion started: 15 January 2018

(c) Author(s) 2018. CC BY 4.0 License.

Kathmandu valley with unique row housing settlements and cultural constructions in the form of vernacular Newari buildings [locally called as 'Chhen']. More than $80 \%$ of buildings in the historic town of Bhaktapur are the brick masonry in mud mortar constructions that are highly vulnerable to earthquake shaking due to lack of several seismic features which will be discussed in the following sections of the paper. Historical records of 1833 earthquake as depicted by Rana (1935) and Bilham (1995)

5 suggest the widespread damage of vernacular masonry buildings in Bhaktapur. Similarly, the accounts of Gupta (1988) and Fujiwara et al. (1989) highlight the consistent scenario of building damage in Bhaktapur; that is severer than the neighboring towns in Kathmandu valley. During 2011 Nepal-Sikkim border earthquake, some brick masonry buildings in Bhaktapur were damage whereas no notable damage was observed in other areas of Kathmandu valley. During Gorkha earthquake, Bhaktapur was the most affected town due to widespread collapse and partial damage of brick masonry buildings. This consistent damage

10 scenario confined to Bhaktapur motivated us to explore the underlying vulnerability of vernacular masonry buildings of Bhaktapur that could be useful in the case of future earthquakes. To fulfill this objective, we interpreted the damage occurrence for available records along with the field investigations performed after 2011 and 2015 earthquakes. Forensic analysis is used to highlight the underlying vulnerability of the vernacular buildings. To the best of authors' knowledge, seismic vulnerability of such vernacular buildings is not reported till now, so we present the detail accounts of forensically interpreted damage

15 scenario during several earthquakes. Moreover, seismic vulnerability of vernacular brick masonry buildings is outlined in terms of damage probability matrices and empirical fragility curves.

\section{Vernacular Newari buildings in Bhaktapur}

Bhaktapur is a densely populated medieval town situated $12 \mathrm{~km}$ east of Kathmandu (Fig. 1). Until 2014, nearly 18600 building were constructed within $6.88 \mathrm{~km}^{2}$ area and more than $80 \%$ of the total buildings were the vernacular brick masonry ones.

20 Vernacular Newari buildings are unreinforced brick masonry buildings usually having three to four stories (Fig. 2). A shallow foundation of bricks is provided in vernacular buildings. The first story comprises large openings to run small businesses whereas the upper stories constitute lesser opening percentage. Vernacular buildings are generally rectangular and constructed usually in gently sloping terrain. The thickness of brick masonry wall varies between 250 and $600 \mathrm{~mm}$ (see Fig. 3). In the third and fourth stories, timber posts are also provided and wooden staircase is provided for vertical transportation. As shown in

25 Fig. 2, first floor is used for commercial activities; second floor is used for bedrooms; third floor is used for living rooms; and the fourth floor is used as kitchen. In general, box gable roof is provided in vernacular masonry buildings, meanwhile, roofing material is dominantly the roof tiles. Upper stories are usually provided with depressed and projected windows whereas the lower stories comprise dormer or lattice windows. Fig. 3 shows a typical section of vernacular brick masonry building that comprises mud mortar, brick layer, wooden plank and timber beam. Two types of wall partitioning can be observed in vernacular buildings: either throughout masonry wall or wooden planks guided one. 
Nat. Hazards Earth Syst. Sci. Discuss., https://doi.org/10.5194/nhess-2017-435

Manuscript under review for journal Nat. Hazards Earth Syst. Sci.

Discussion started: 15 January 2018

(c) Author(s) 2018. CC BY 4.0 License.

\section{Seismic performance of vernacular Newari buildings during major earthquakes}

\subsection{Bihar-Nepal earthquake}

The 1934 Bihar-Nepal earthquake is the strongest earthquake $\left(\mathrm{M}_{\mathrm{W}} \sim 8.4\right)$ in the modern history of Nepal. The epicenter of the earthquake was in eastern Nepal and the effect of earthquake was observed throughout Nepal and northern India. Rana (1935)

5 reported the focal depth to be $\sim 24-40$ miles taking into consideration of public opinion. Rana (1935) reported that the effective shaking was of 2-3 minutes and whereas the total shaking was felt for around 8 minutes. Furthermore, Rana (1935) noted that the shaking was initially horizontal and then circular. Vertical shaking was also reported to be dominant by Rana (1935) during Bihar-Nepal earthquake. Rana (1935) estimated the ground peak ground velocity in the range of 285-345 cm/s, although this estimation comes from Rana's own experience, however, such figures depict strong ground shaking during the earthquake.

10 Although, the epicenter of the earthquake was nearly $150 \mathrm{~km}$ east of Bhaktapur, severe damage was occurred in Bhaktapur. Such intense damage was attributed to site characteristics of Bhaktapur (alluvial deposit), construction technology, building population and vulnerability of building stocks. Reports of building damage due to Bihar-Nepal earthquake are presented in the following section.

\subsubsection{Reported building damage in Bhaktapur}

15 In total, 6224 residential buildings were damaged due Bihar-Nepal earthquake (Rana, 1935). More than 177 heritage structures were also damaged due to the earthquake. The most common failure mode was reported to be the combination of in plane and out of plane mechanism as shown in Fig. 4a. Apart from this, poor binding among the masonry units can be observed in damaged wall section. Fig. 4b depicts the collapse of heavy gable wall as contemporary practices were based on homogenous walls throughout the building.

20 Rana (1935) reported that the damage range was between 40-100\% for various settlements within the town and outlined the causes of damage as: a) multistoried buildings; b) buildings with higher opening percentage; c) structural pounding in case of row housing; d) buildings constructed with low quality bricks (unbaked ones) ; e) improper bonding between the brick units; f) load concentration in the upper stories and gable; g) poor site selection and foundation problem (unleveled); h) buildings undergone with incremental construction; i) projections; and j) lack of integrity between the orthogonal walls.

25 Pictures of damage taken by Rana (1935) confirm that the buildings in the corner of row housing settlements were damaged more than the standalones. This may be due to combination of vulnerability as well as additional lateral load imposed by other structures.

The description presented by Rana (1935) also considered some of the improvement measures for post-earthquake reconstruction as: a) use well dried and proper dimension bricks with smooth finish for construction; b) Oil mixed and dried

30 bricks "Chiga: appa" is better than other brick types; c) do not construct more than a story with raw bricks; d) use light roofing; e) limit the height of vernacular buildings to $51 \mathrm{ft}$;; f) mix cow dung for improved mortar quality; g) use timber posts rather than brick pillars; h) avoid river banks, land plots beside the ponds for construction; i) provide timber band "Nas" in in masonry 
Nat. Hazards Earth Syst. Sci. Discuss., https://doi.org/10.5194/nhess-2017-435

Manuscript under review for journal Nat. Hazards Earth Syst. Sci.

Discussion started: 15 January 2018

(c) Author(s) 2018. CC BY 4.0 License.

walls; j) reduce weight of gable portion; k) provide sufficient masonry wall in between the openings; 1) lime as mortar is superior than mud mortar or mud with cow dung; m) determine building height and foundation depth per the quality of construction materials.

\subsection{Udaypur earthquake}

5 After the 1934 earthquake, Bhaktapur was hit by several moderate earthquakes until 1988, however, notable structural damage was not reported. Udaypur earthquake $\left(\mathrm{M}_{\mathrm{W}} 6.8\right)$ occurred in $1988 \sim 150 \mathrm{~km}$ southeast of Kathmandu. During this earthquake, Bhaktapur was the most affected town in Kathmandu valley. The Modified Mercalli Intensity (MMI) for Kathmandu valley was assigned to be $\mathrm{V}$ and peak ground acceleration was estimated to be $\sim 20-50$ gals (Fujiwara et al., 1989). The maximum MMI intensity for Bhaktapur was estimated $~ 7.40$ whereas neighboring towns Kathmandu and Patan were assigned to 6.67

10 and 6.57 maximum intensity respectively by Fujiwara et al. (1989). Gupta (1988) and Fujiwara et al. (1989) reported that most of the damaged buildings were the survivors of the 1934 earthquakes.

\subsubsection{Reported building damage in Bhaktapur}

During Udaypur earthquake 274 buildings collapsed and other 1477 buildings observed partial damage throughout Bhaktapur district. Due to lack of statistical records in localized scale, exact scenario of damage distribution is not possible to outline;

15 however, the descriptions provided by Gupta (1988), Fujiwara et al. (1989) and Dixit (1991) suggest that the town of Bhaktapur was the most affected. Fujiwara et al. (1989) has reported that the houses partly damaged during 1934 earthquake were used without any repair and the damage was intense in such structures. The construction practices as highlighted by Gupta (1988) and Fujiwara et al. (1989) reflect that there were no indications of the improved construction practice per the recommendations of Rana (1935) after the 1934 earthquake. Gupta (1988) and Fujiwara et al. (1989) identified the causes of building damage

20 in Bhaktapur as: a) buildings situated in sloping ground (Fig. 5); b) building constructed using mud-mortar; c) buildings constructed up to four to five stories in brick masonry without any earthquake resistant provision (Fig. 5); d) structural pounding (Fig. 6); e) poor quality of construction material for foundation; f) poor mortar quality; g) separation of masonry units due to shrinkage in mud-mortar; h) marginal construction in corner joints and joints occurring in between different walls within the diaphragm; i) non-dried clay bricks used in walls; j) lack of diaphragm action due to improper timber joists; $k$ ) heavy gable construction and roofing (Fig. 7); 1) heavy masonry wall (thickness $\sim 500 \mathrm{~mm}$ ); m) in-plane and out-of-plane mechanisms (Fig. 8); n) improper opening placement (Fig. 9); and o) cantilevered projections.

Following their field investigation, Fujiwara et al. (1989) recommended some measures for earthquake resistant constructions as: a) lower the overall building weight by avoiding the brick topping on floor level and replacing the heavy roof by corrugated iron sheets or thatch; b) restrain the gable wall along with the main structural walls below it so that a matchbox type

30 construction could be developed that assures better structural integrity; c) place horizontal bracing for roof and floor slabs and also provide diagonal bracing at the corners; and d) improve mortar quality. 
Nat. Hazards Earth Syst. Sci. Discuss., https://doi.org/10.5194/nhess-2017-435

Manuscript under review for journal Nat. Hazards Earth Syst. Sci.

Discussion started: 15 January 2018

(c) Author(s) 2018. CC BY 4.0 License.

\subsection{Sikkim-Nepal border earthquake}

The Sikkim-Nepal border earthquake ( $\mathrm{M}_{\mathrm{W}}$ 6.9) affected primarily eastern Nepal but few cases of vernacular masonry damage in Bhaktapur were observed during the field reconnaissance. The earthquake occurred $\sim 270 \mathrm{~km}$ east of Kathmandu valley at a focal depth of $19.7 \mathrm{~km}$ (USGS 2011).

5 During the field investigation, it was known that the damaged buildings were the ones already partially damaged due to 1988 Udyapur earthquake. Although the accelerometric records in Kathmandu valley show low peak ground acceleration $(\sim 0.05 \mathrm{~g})$, some of the buildings in Bhaktapur sustained partial collapse and some others sustained partial damage. Interestingly, some of the already bulged buildings due to the 1988 Udaypur earthquake remained unaffected in some locations of Bhaktapur. Notably, two cases of out of plane wall collapse were observed (Fig. 10a) in Bhaktapur. In addition, one case of structural

10 pounding was noted probably due to sharp variation in dynamic properties among the adjoin buildings (Fig. 10b). Damages in heavy gable wall (Fig. 11a), cracks on masonry walls especially at corner region (Fig. 11b), and damage in heavy roof (Fig. 11c) were identified other observed damage modes during the field reconnaissance. Since1934, the construction strategy was not found to be changed as the similar failure modes and construction materials and technology were observed during field reconnaissance.

\section{$15 \quad 3.4$ Gorkha earthquake}

The 2015 Gorkha earthquake ( $\mathrm{M}_{\mathrm{W}}$ 7.8) affected the ancient Bhaktapur town heavily that can be roughly compared to the damage occurred during 1934 earthquake. The epicenter of Gorkha earthquake was located $\sim 78 \mathrm{~km} \mathrm{N-NE}$ of Kathmandu valley in Barpak village of Gorkha district. Several factors like local amplification and construction technology responsible for structural damage and the accounts of building damage in regional scale are presented by Gautam et al. (2016) and Gautam

20 and Chaulagain (2016). In the case of Bhaktapur, almost $80 \%$ building stocks were the vernacular Newari houses and most of remaining buildings were the substandard RC buildings (for details see: Chaulagain et al. (2013). During Gorkha earthquake, relatively lower value of PGA and short duration of shaking may have altered the damage scenario and hence previous loss estimation models depicted by Chaulagain et al. (2016) was not able to represent the actual damage scenario.

\subsubsection{Report of building damage in Bhaktapur}

25 Although the intensity of earthquake in Kathmandu valley was generally VIII, some areas of Bhaktapur like; Golmadhi, Suryamadhi, Jela, Byasi were destroyed; that leads in greater than VIII intensity. In the follwoign section of the manuscript, we have assigned IX intensity for Bhaktapur to derive the fragility functions. local scale. Fig. 12 depicts the major collapse locations within Bhaktapur; destroyed settlements are highlighted by large red bubbles. Apart from this, slight, minor and heavy damages were observed in all parts of the town. The major damage locations were towards the eastern fringe of the town and the settlements located on the sloping ground. The summary of component-wise failure modes is presented in Table 1. 
Nat. Hazards Earth Syst. Sci. Discuss., https://doi.org/10.5194/nhess-2017-435

Manuscript under review for journal Nat. Hazards Earth Syst. Sci.

Discussion started: 15 January 2018

(c) Author(s) 2018. CC BY 4.0 License.

\subsubsection{Seismic features in vernacular Newari buildings}

During field investigation, apart from the widespread damage, significant survival cases were also identified. We observed that the buildings consisting some specific features were either lowly damaged or undamaged when compared to the buildings without such features. We observed that, the features highlighted in Table 2 effectively contributed in collapse prevention and in many cases life safety should have been facilitated by such components too. Table 2 outlines the identified seismic features in vernacular Newari buildings of Bhaktapur.

\section{Construction of DPM and fragility functions}

Seismic vulnerability of buildings is either presented in terms of damage probability matrices (DPM) or fragility functions (Elnashai and Di Sarno, 2000). Many researchers have formulated fragility functions for buildings worldwide using either

10 analytical (e.g. Hassan and Sozen, 1997; Erberik and Elnashai, 2004; Rota et al., 2010; Parisi and Sabella, 2017), empirical (e.g. Sabetta et al., 1998; Yamazaki and Murao, 2000; Rossetto and Elnashai, 2003; Gautam, 2017), hybrid (e.g. Kappos et al. 2006; Kappos and Panagopoulos, 2010) or expert opinion (e.g. ATC, 1985; ATC, 1996) approaches. To the best of authors' knowledge, fragility functions for traditional Newari buildings do not exist, however their vulnerability is important due to their large population in major urban centers of Kathmandu valley. To address the lack of vulnerability functions or DPM, we

15 have created DPM as well fragility functions using the database of 1934, 1988 and 2015 earthquakes. To create the DPMs, we first defined the mean damage ratio (MDR) for three intensity levels. The mean damage ratio (MDR) at given intensity level (I) can be calculated as:

$\operatorname{MDR}(I)=\Sigma_{D S} P(D S, I) \times C D R(D S)$,

Where $M D R(I)$ is mean damage ratio at given intensity; $P(D S, I)$ is the damage state probability of defined building type; and

$20 C D R(D S)$ indicates central damage ratio corresponding to the damage state DS. The damage state probability $\mathrm{P}$ (DS, I) can be calculated as below:

$P(D S, I)=\frac{N(D S, I)}{N(I)}$

Where $N(D S, I)$ denotes the number of buildings in damage state $D S$; and $N(I)$ indicates the total number of buildings subjected to the earthquake event. DPMs for VIII, IX and X intensity levels were derived based on the damage data available

25 from historical accounts. The DPMs for traditional masonry buildings is presented in Table 3 . The DPMs were subsequently converted into fragility functions by as shown in Fig. 21.

The database was taken from Rana (1935), Gupta (1988), Fujiwara et al. (1989), NPC (2015) and some news outlets. To create fragility functions, we considered peak ground velocity (PGV) as intensity measure (IM) that was estimated from the Modified Mercalli Intensity ( $\left.\mathrm{I}_{\mathrm{MM}}\right)$ using the correlation proposed by Wald et al. (1999) as: 
Nat. Hazards Earth Syst. Sci. Discuss., https://doi.org/10.5194/nhess-2017-435

Manuscript under review for journal Nat. Hazards Earth Syst. Sci.

Discussion started: 15 January 2018

(c) Author(s) 2018. CC BY 4.0 License.
Natural Hazards

and Earth System

Sciences

Discussions

(c) (i)

The estimated peak ground velocities from each of the earthquake were employed to calculate the lognormal distribution parameters as intensity measures (IMs). Several previous studies confirm the lognormal distribution as the representative statistical distribution (e.g. Porter and Kiremidjian, 2001; Beck et al., 2002; Pagni and Lowes, 2006), accordingly we use the lognormal distribution in this study. Two-parameter lognormal cumulative distribution function used to define the fragility

5 functions can be written as:

$F(C \mid I M=x)=\Phi\left(\frac{\ln (x / \varepsilon)}{\beta}\right)$,

Where $F(C \mid I M=x)$ indicates the probability that a ground motion with $I M=x$ will cause the given damage state (minor, severe, collapse); $\Phi(\cdot)$ is the standard normal cumulative distribution function; $\varepsilon$ is the median of the fragility function; and $\beta$ is the logarithmic standard deviation. A summary of the estimated lognormal distribution parameters for minor, severe and collapse damage states is also presented in Table 4 below. Fragility functions for three damage states are derived from the damage data of 1934, 1988 and 2015 earthquakes as shown in Fig. 22.

\section{Construction of DPM and fragility functions}

Our observations and forensic analysis has led us to conclude that the vernacular Newari buildings are likely to be severely damaged in the case of strong to major earthquakes (MMI $\geq$ VIII). Due to lack of periodic strengthening and repairs after the

15 earthquakes and unrelenting use, vulnerability of vernacular buildings in Bhaktapur is very high that may lead to collapse even at moderate shaking. We have presented the damage modes from four earthquakes (1934, 1988, 2011 and 2015$)$, and forensic interpretations confirm that there is not substantial change in the traditional construction practices between 1934 and 2015. The damage probability matrices and fragility functions created from the damage data depict that the collapse damage state is more likely than any other in the case of strong to major earthquakes and that may drastically increase the fatality rate. The upshot of this is the possibility that the damage in Bhaktapur will be greater than any other areas if the vulnerable structures are not strengthened immediately. This research has underlined the importance of identification of local seismic features that could effectively downscale the building collapse. The most important limitation of this research lies in the use of empirical database to create fragility functions, so future studies should develop analytical models to create analytical fragility functions. This is the first step towards enhancing the understanding of seismic vulnerability of vernacular Newari buildings and further work needs to be done to establish possible low cost strengthening solutions as well as retrofitting strategies.

\section{Acknowledgments}

Authors are grateful to Ganesh Kumar Bhattarai, Raghu N Prajapati, Jastara Koju, Dhira Phadera, Bharat Chandra Hada, and many other local from Bhaktapur who assisted in collection of information from various sources. 
Nat. Hazards Earth Syst. Sci. Discuss., https://doi.org/10.5194/nhess-2017-435

Manuscript under review for journal Nat. Hazards Earth Syst. Sci.

Discussion started: 15 January 2018

(c) Author(s) 2018. CC BY 4.0 License.

\section{References}

ATC (Applied Technology Council): Earthquake damage evaluation data for California, ATC-13, Applied Technology Council, California, 1985.

ATC (Applied Technology Council): Seismic evaluation and retrofit of concrete buildings, ATC-40, Applied Technology Council, California, 1996.

Beck, J.L., Porter, K.A., Shaikhutdinov, R., Au, S.K., Mizukoshi, K., Miyamura, M., Ishida, H., Moroi, T., Tsukada, Y., and Masuda, M.: Impact of seismic risk on lifetime property values, final report, CUREE, Richmond, CA, 2002.

Bilham, R.: Location and magnitude of the 1833 Nepal earthquake and its relation to the rupture zones of contiguous great Himalayan earthquakes, Current Science, 69(2), 155-187, 1995.

10 Chaulagain, H., Rodrigues, H., Jara, J., Spacone, E., and Varum, H.: Seismic response of current RC buildings in Nepal: comparative analysis of different design/construction, Engineering Structures, 49:284-294, 2013.

Chaulgain, H., Rodrigues, H., Silva, V., Spacone, E., and Varum, H.: Earthquake loss estimation for the Kathmandu valley, Bulletin of Earthquake Engineering, 14, 59-88, 2016.

Dixit, A.M.: Geological effects and intensity distribution of the Udaypur (Nepal) earthquake of August 20, 1988, Journal of Nepal Geological Society, 7:1-17, 1991.

Elnashai, A.S., and Di Sarno, L.: Fundamentals of earthquake engineering, Wiley and Sons, West Sussex, United Kindgodm, 2000.

Erberik, M.A., and Elnashai, A.S.: Fragility analysis of flat-slab structures, Engineering Structures, 26(7), 937-948, 2004.

Fujiwara, T., Sato, T., Murakami, H.O., and Kubo, T.: Reconnaissance report on the 21 August 1988 earthquake in the NepalIndia border region, Research Report on Natural Disasters, Japanese Group for the Study of Natural Disaster Science, Tokyo, 1989.

Gautam, D.: On seismic vulnerability of highway bridges in Nepal: 1988 Udaypur earthquake $\left(\mathrm{M}_{\mathrm{W}}\right.$ 6.8) revisited, Soil Dynamics and Earthquake Engineering, 99, 168-171, 2017.

Gautam, D., Rodrigues, H., Bhetwal, K.K., Neupane, P., and Sanada, Y.: Common structural and construction deficiencies of Nepalese buildings, Innovative Infrastructure Solutions, 1: 1. doi:10.1007/s41062-016-0001-3, 2016.

Gautam, D., and Chaulagain, H.: Structural performance and associated lessons to be learned from world earthquakes in Nepal after 25 April 2015 ( $\mathrm{M}_{\mathrm{W}}$ 7.8) Gorkha earthquake, Engineering Failure Analysis, 68, 222-243, 2016.

Gupta, S.P.: Eastern Nepal earthquake 21 August 1988, damage and recommendations for repairs and reconstruction, Asian Disaster Preparedness Center, Bangkok, 1988.

Hassan, A.F., and Sozen, M.A.: Seismic vulnerability assessment of low-rise buildings in regions with infrequent earthquakes, ACI Structural Journal, 94(1), 31-39, 1997. 
Nat. Hazards Earth Syst. Sci. Discuss., https://doi.org/10.5194/nhess-2017-435

Manuscript under review for journal Nat. Hazards Earth Syst. Sci.

Discussion started: 15 January 2018

(c) Author(s) 2018. CC BY 4.0 License.

(c) (i)
Natural Hazards

and Earth System

Sciences

Discussions

Kappos, A.J., Panagopoulos, G., Panagiotopoulos, C., and Penelis, G.: A hybrid method for the vulnerability assessment of R/C and URM buildings, Bulletin of Earthquake Engineering, 4(4), 391-413, 2006.

Kappos, A.J., and Panagopoulos, G.: Fragility curves for reinforced concrete buildings in Greece, Structures and Infrastructure Engineering, 6(1-2), 39-53, 2010.

5 NPC (National Planning Commission): Post Disaster Need Assessment Vol. A and B. Kathmandu: Government of Nepal; 2015.

Pagni, C.A., and Lowes, L.N.: Fragility functions for older reinforced concrete beam-column joints, Earthquake Spectra, 22, 215-238, 2006.

Parisi, F., and Sabella, G.: Flow type landslide fragility of reinforced concrete framed buildings, Engineering Structures, 131, 28-43, 2017.

Porter, K.A., and Kiremidjian, A.S.: Assembly-based vulnerability and its uses in seismic performance evaluation and riskmanagement decision-making, Report No. 139, John A. Blume Earthquake Engineering Center, Stanford, CA, 2001.

Rana, B.S.J.B.: The great earthquake of Nepal (Nepalko Mahabhukampa) [in Nepali], Jorganesh Press, Kathmandu, 1935.

Rossetto, T., and Elnashai, A.S.: Derivation of vulnerability functions for European-type RC structures based on observational data, Engineering Structures. 25(10), 1241-1263, 2003.

Rota, M., Penna, A., and Magenes, G.: A methodology for deriving analytical fragility curves for masonry buildings based on stochastic nonlinear analyses, Engineering Structures, 32(5), 1312-1323, 2010.

Sabetta, F., Goretti, A., and Lucantoni, A.: Empirical fragility curves from damage surveys and estimated strong ground motion, Proceedings of the 11th European Conference on Earthquake Engineering, Paris, France, pp. 1-11, 1998.

20 USGS (United States Geological Survey). 2011. http://earthquake.usgs.gov/earthquakes/eqinthenews/2011/usc0005wg6/

Wald, D.J., Quitoriano, V., Heaton, T.H., and Kanamori, H.: Relationships between peak ground acceleration, peak ground velocity, and Modified Mercalli Intensity in California, Earthquake Spectra, 15(3), 557-564, 1999.

Yamazaki, F., and Murao, O.: Vulnerability functions for Japanese buildings based on damage data from the 1995 Kobe earthquake, Implication of Recent Earthquakes on Seismic Risk, Series on Innovation and Construction, Imperial College Press, vol. 2, pp. 91-102, 2000. 
Nat. Hazards Earth Syst. Sci. Discuss., https://doi.org/10.5194/nhess-2017-435

Manuscript under review for journal Nat. Hazards Earth Syst. Sci.

Discussion started: 15 January 2018

(c) Author(s) 2018. CC BY 4.0 License.

(c) (1)

\section{Natural Hazards and Earth System \\ Sciences \\ Discussions}

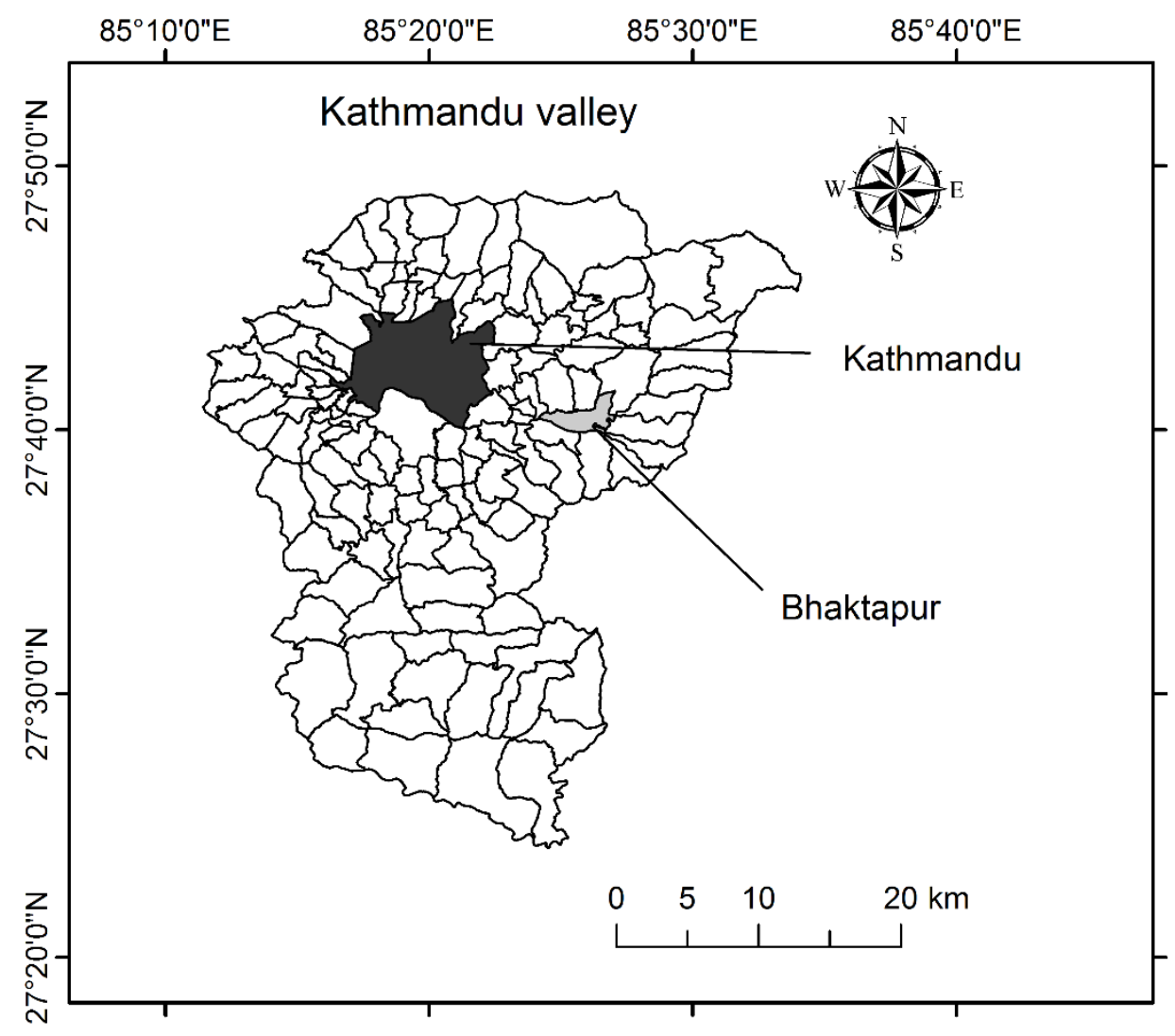

Figure 1: 1 Location of Bhaktapur in Kathmandu valley. 
Nat. Hazards Earth Syst. Sci. Discuss., https://doi.org/10.5194/nhess-2017-435

Manuscript under review for journal Nat. Hazards Earth Syst. Sci.

Discussion started: 15 January 2018

(c) Author(s) 2018. CC BY 4.0 License.

(c) (1)

\section{Natural Hazards and Earth System \\ Sciences \\ Discussions}

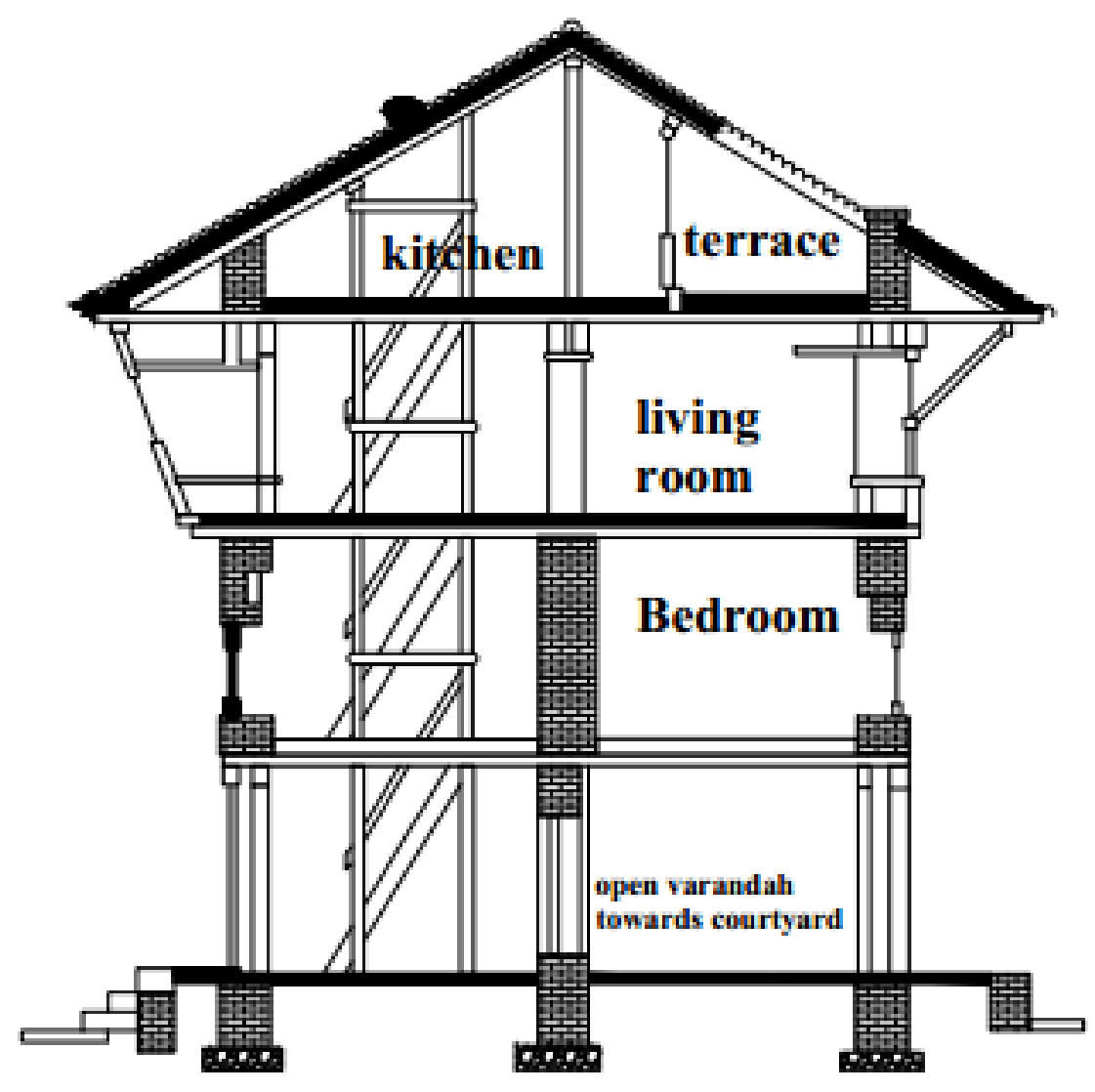

Figure 2: Vernacular brick masonry building. 
Nat. Hazards Earth Syst. Sci. Discuss., https://doi.org/10.5194/nhess-2017-435

Manuscript under review for journal Nat. Hazards Earth Syst. Sci.

Discussion started: 15 January 2018

(C) Author(s) 2018. CC BY 4.0 License.

\section{(c) (1)}

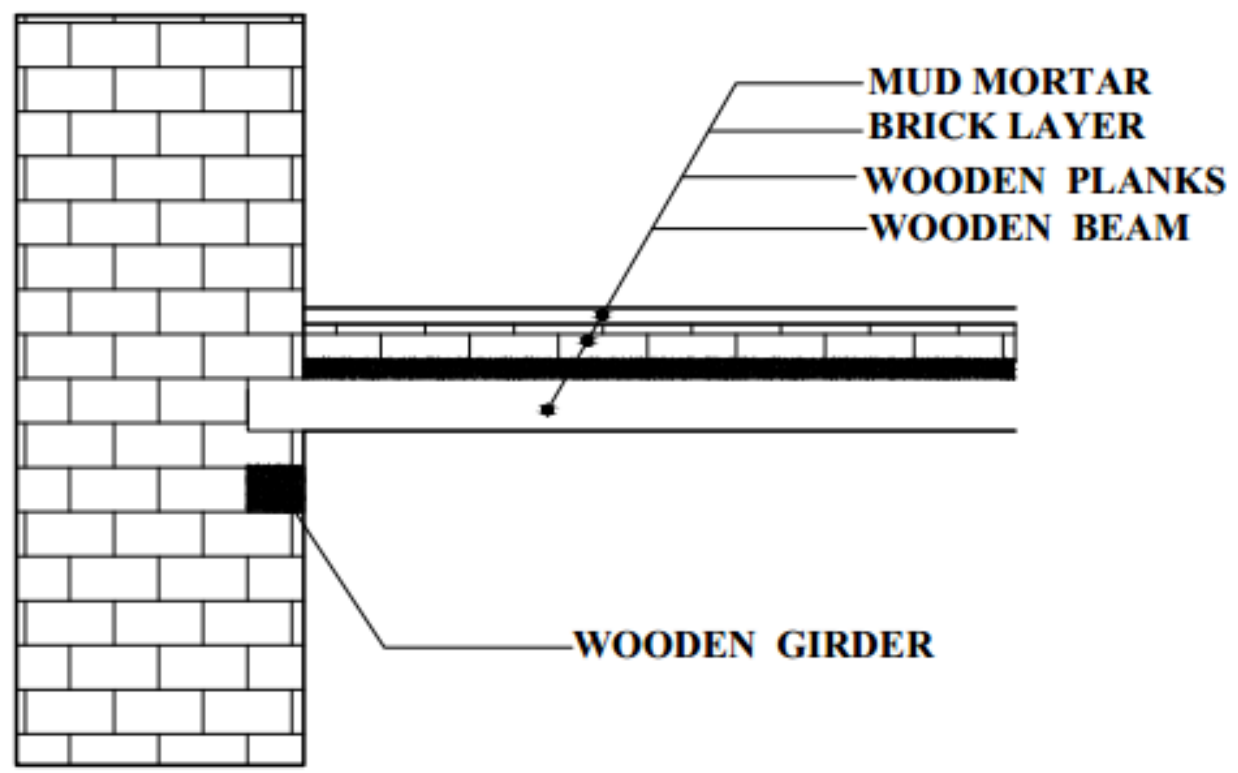

Natural Hazards $\frac{0}{5}$ and Earth System

Sciences

Discussions

Figure 3: A section of the masonry wall. 
Nat. Hazards Earth Syst. Sci. Discuss., https://doi.org/10.5194/nhess-2017-435

Manuscript under review for journal Nat. Hazards Earth Syst. Sci.

Discussion started: 15 January 2018

(c) Author(s) 2018. CC BY 4.0 License.

\section{Natural Hazards and Earth System Sciences \\ Discussions}
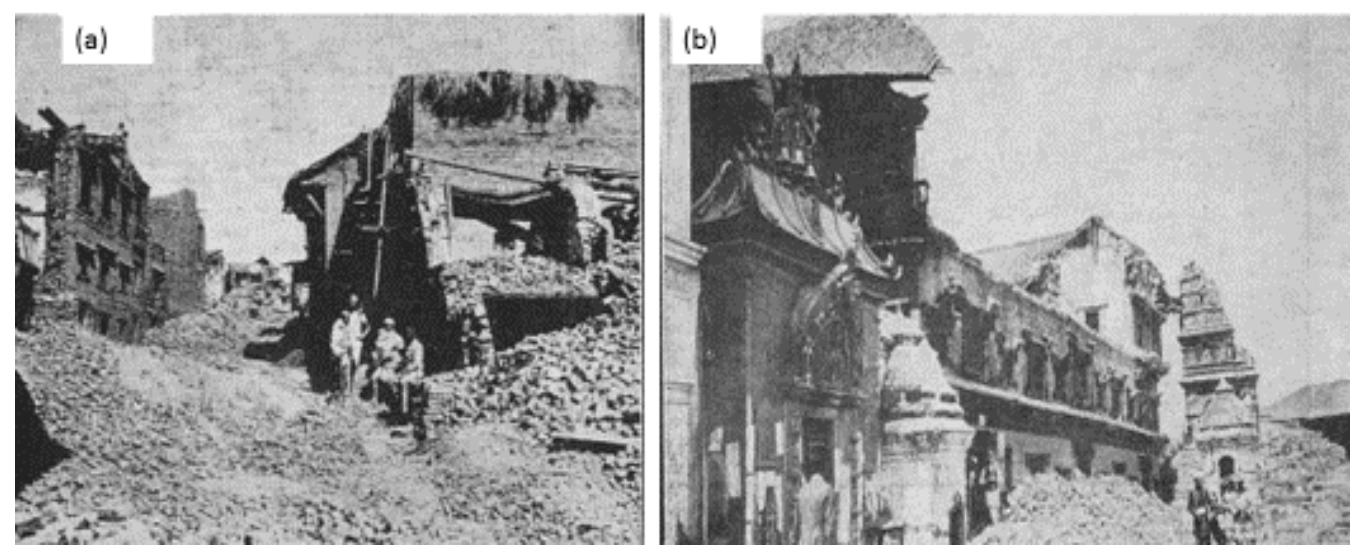

Figure 4: (a) Combined in-plane and out-of-plane failure in masonry walls (courtesy: Rana (1935)) (b) Collapse occurred in the upper story due to mass concentration (courtesy: Rana (1935)). 
Nat. Hazards Earth Syst. Sci. Discuss., https://doi.org/10.5194/nhess-2017-435

Manuscript under review for journal Nat. Hazards Earth Syst. Sci.

Discussion started: 15 January 2018

(c) Author(s) 2018. CC BY 4.0 License.

(c) (1)

\section{Natural Hazards and Earth System Sciences \\ Discussions}

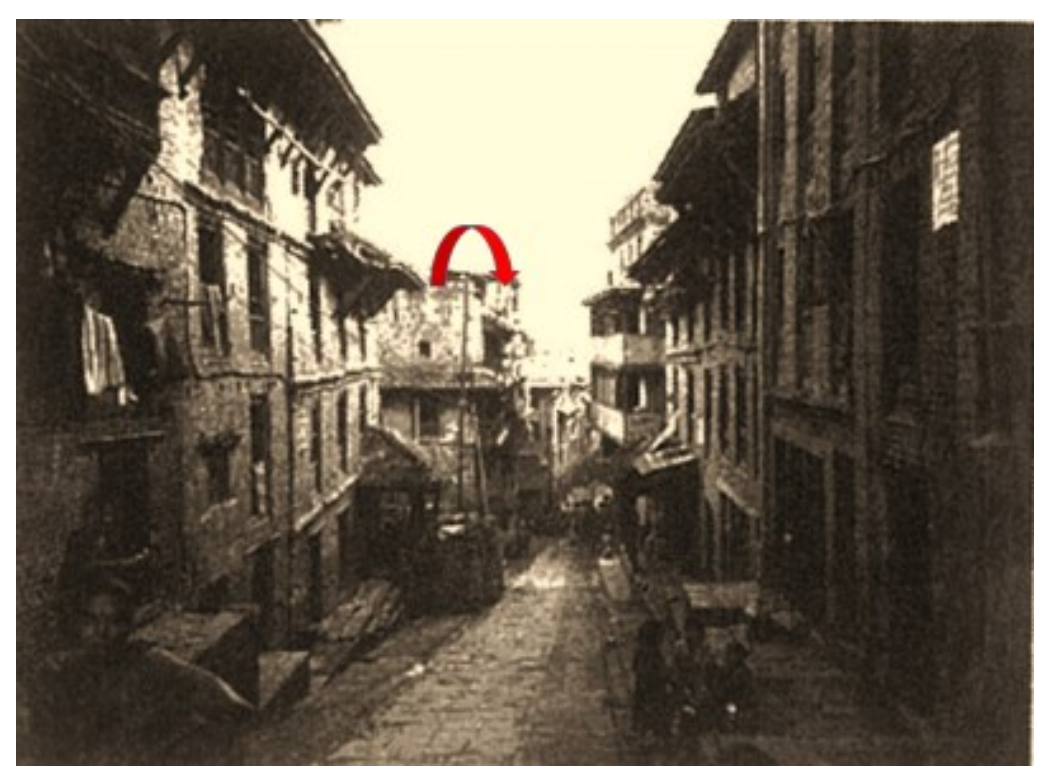

Figure 5: Damaged houses in sloping ground due to 1988 earthquake (courtesy: Gupta (1988)). 
Nat. Hazards Earth Syst. Sci. Discuss., https://doi.org/10.5194/nhess-2017-435

Manuscript under review for journal Nat. Hazards Earth Syst. Sci.

Discussion started: 15 January 2018

(c) Author(s) 2018. CC BY 4.0 License.

(c) (1)

\section{Natural Hazards and Earth System Sciences \\ Discussions}

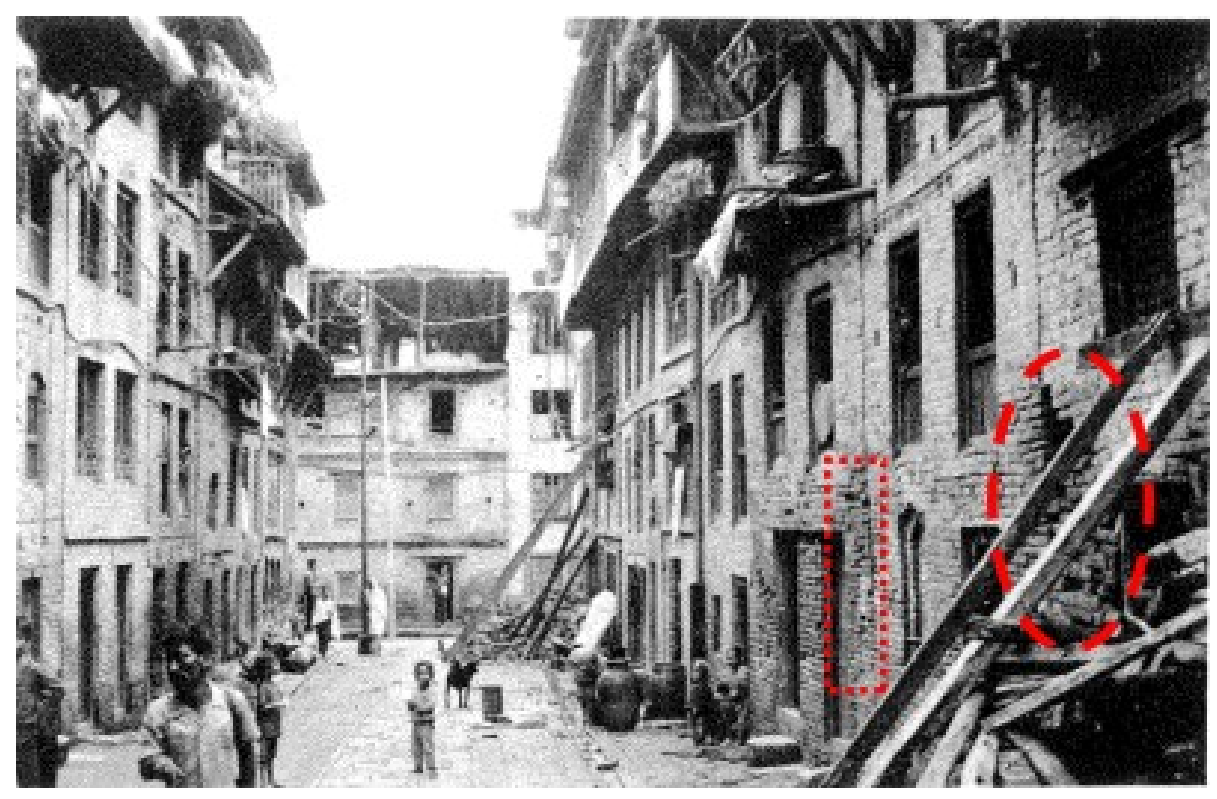

Figure 6: Damage due to structural pounding occurred due to 1988 earthquake (courtesy: Gupta (1988)). 
Nat. Hazards Earth Syst. Sci. Discuss., https://doi.org/10.5194/nhess-2017-435

Manuscript under review for journal Nat. Hazards Earth Syst. Sci.

Discussion started: 15 January 2018

(c) Author(s) 2018. CC BY 4.0 License.

\section{(c) (1)}

\section{Natural Hazards and Earth System Sciences \\ Discussions}

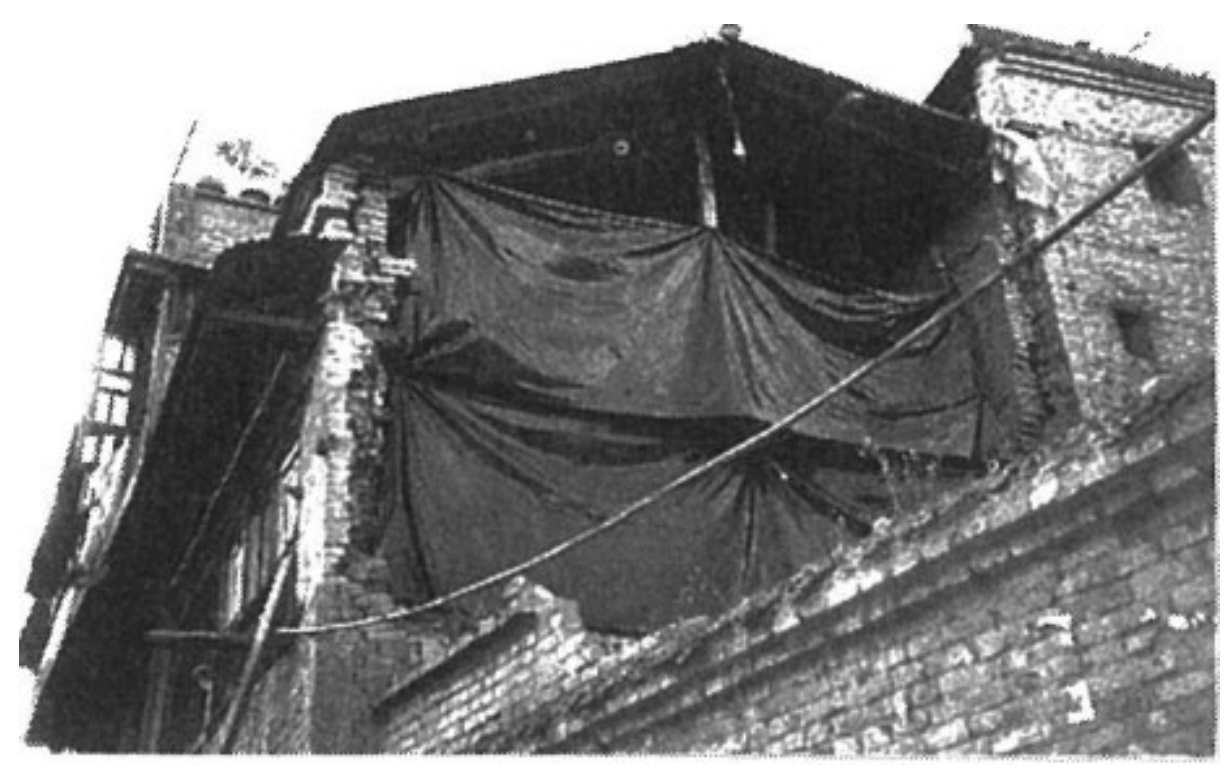

Figure 7: Gable collapse reported by Fujiwara et al. (1989) during 1988 earthquake. 
Nat. Hazards Earth Syst. Sci. Discuss., https://doi.org/10.5194/nhess-2017-435 Manuscript under review for journal Nat. Hazards Earth Syst. Sci.

Discussion started: 15 January 2018

(c) Author(s) 2018. CC BY 4.0 License.

\section{Natural Hazards and Earth System Sciences \\ Discussions}

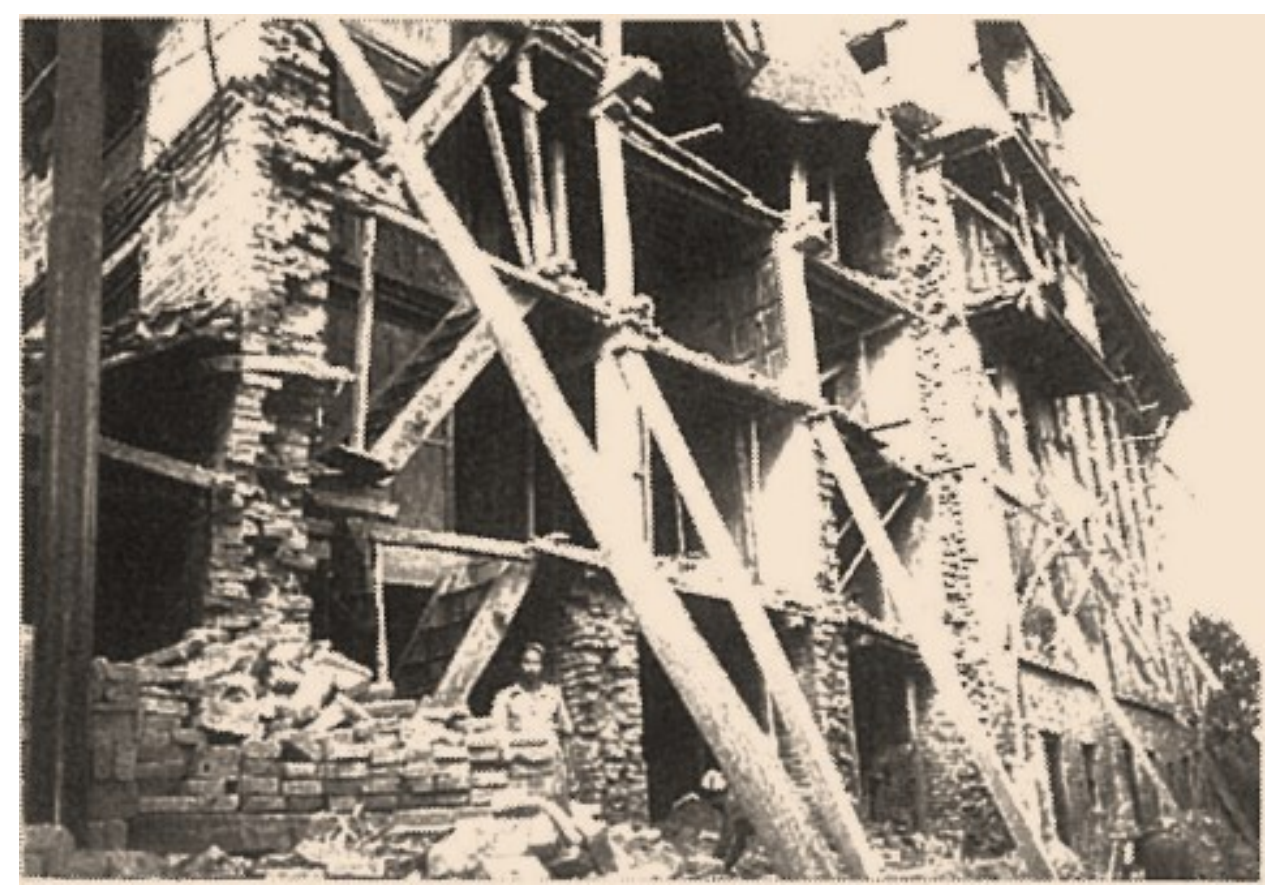

Figure 8: Damage due to in-plane and out-of-plane actions during 1988 earthquake (courtesy: Fujiwara et al. (1989)). 
Nat. Hazards Earth Syst. Sci. Discuss., https://doi.org/10.5194/nhess-2017-435 Manuscript under review for journal Nat. Hazards Earth Syst. Sci.

Discussion started: 15 January 2018

(c) Author(s) 2018. CC BY 4.0 License.

(c) (i)

\section{Natural Hazards and Earth System \\ Sciences \\ Discussions}

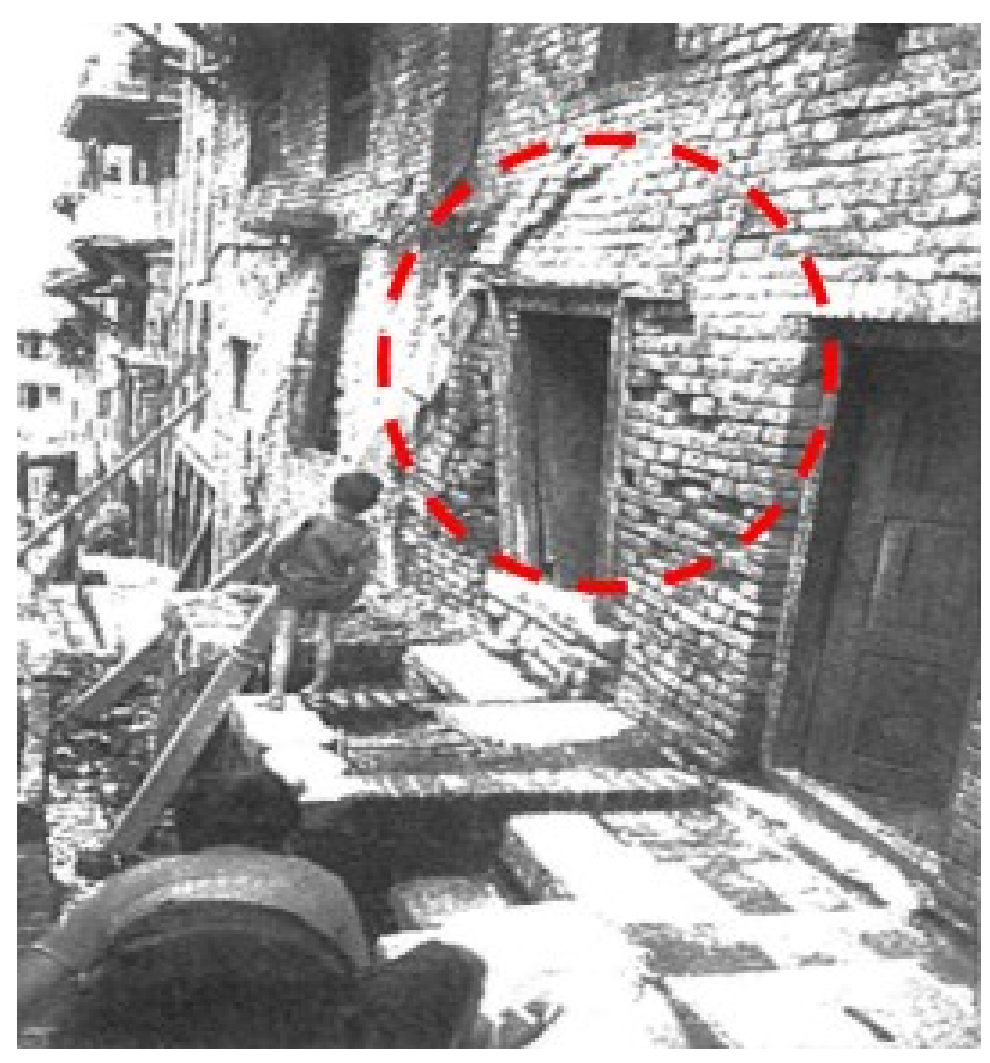

Figure 9: Bulging of wall observed above the doors due to 1988 earthquake (courtesy: Fujiwara et al. (1989)). 
Nat. Hazards Earth Syst. Sci. Discuss., https://doi.org/10.5194/nhess-2017-435

Manuscript under review for journal Nat. Hazards Earth Syst. Sci.

Discussion started: 15 January 2018

(c) Author(s) 2018. CC BY 4.0 License.

\section{(c) (i)}
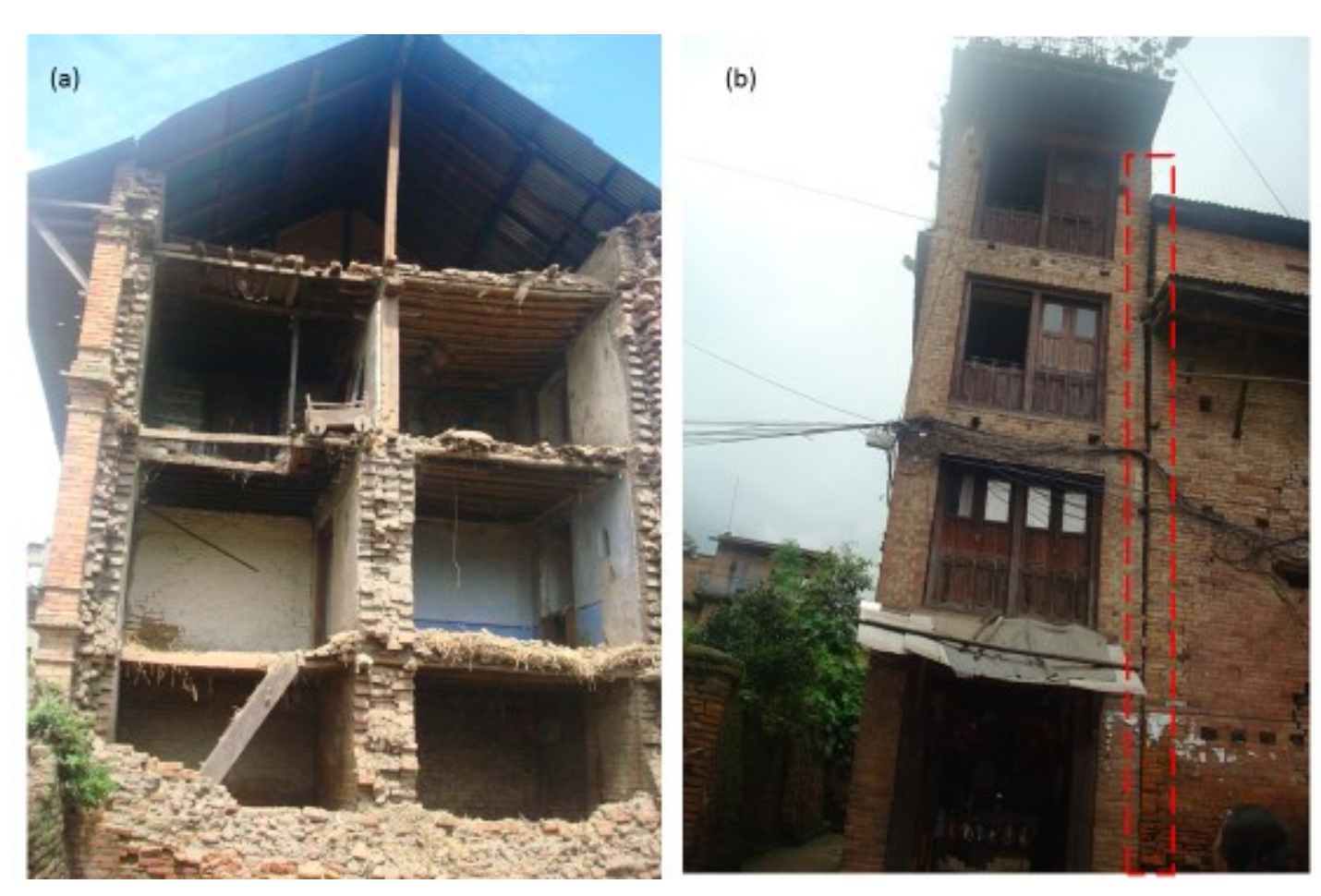

Figure 10: (a) Out of plane collapse of masonry wall (courtesy: Ganesh Kumar Bhattarai), and (b) structural pounding due to 2011 earthquake (courtesy: Ganesh Kumar Bhattarai).

\section{Natural Hazards 웅 and Earth System \\ Sciences \\ Discussions}


Nat. Hazards Earth Syst. Sci. Discuss., https://doi.org/10.5194/nhess-2017-435 Manuscript under review for journal Nat. Hazards Earth Syst. Sci.

Discussion started: 15 January 2018

(c) Author(s) 2018. CC BY 4.0 License.

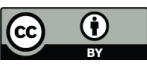

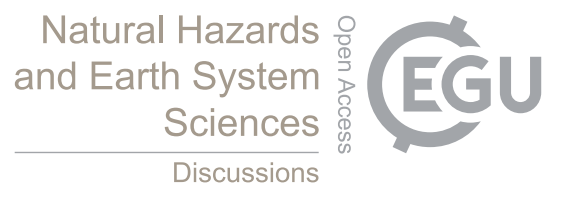
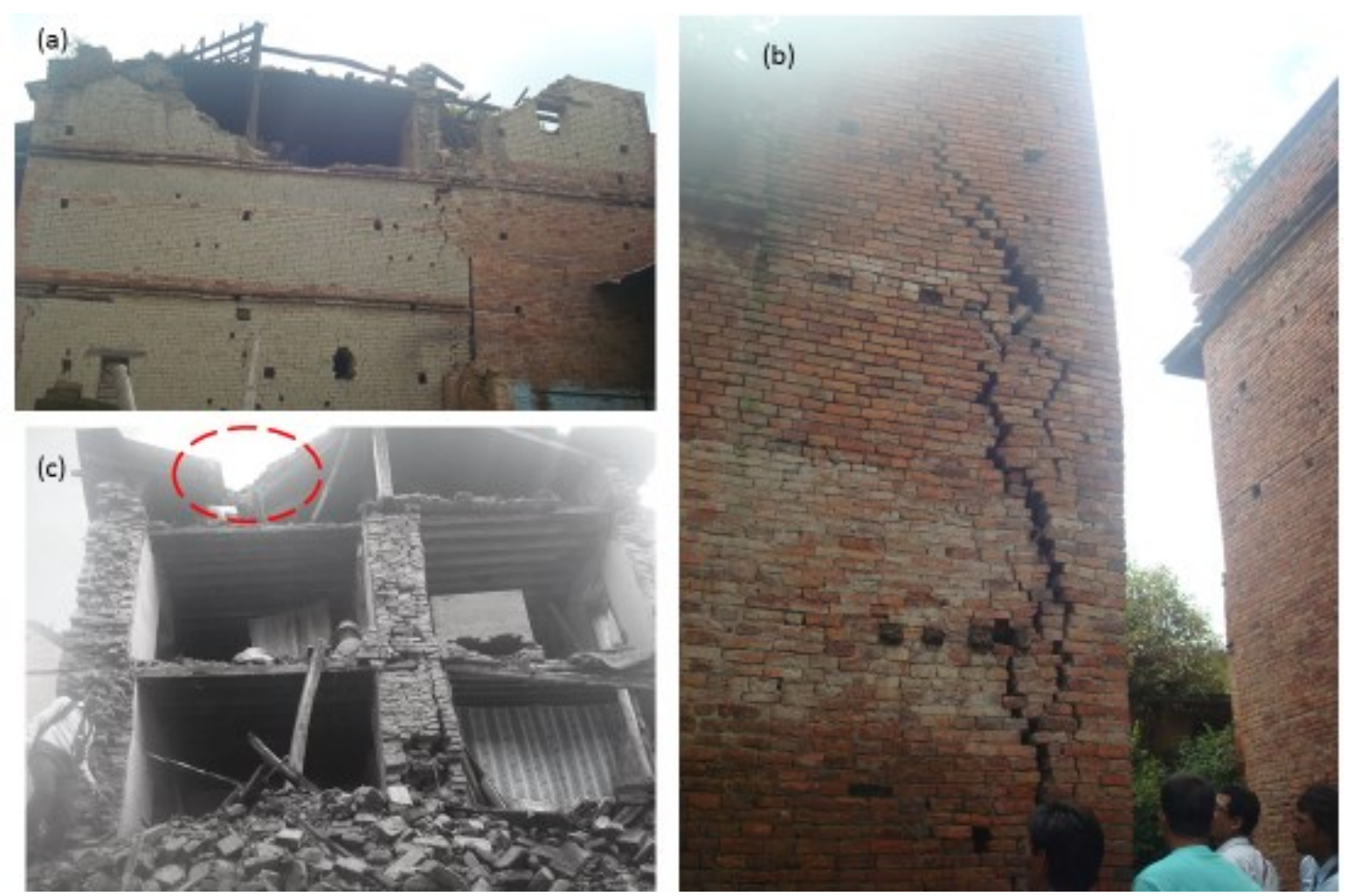

Figure 11: (a) Gable collapse occurred in two adjoining buildings (courtesy: Ganesh Kumar Bhattarai), (b) cracks propagated towards the corners (courtesy: Ganesh Kumar Bhattarai), (c) heavy roof collapse and out of plane failure of brick masonry wall occurred due to 2011 earthquake (courtesy: Ganesh Kumar Bhattarai). 
Nat. Hazards Earth Syst. Sci. Discuss., https://doi.org/10.5194/nhess-2017-435

Manuscript under review for journal Nat. Hazards Earth Syst. Sci.

Discussion started: 15 January 2018

(c) Author(s) 2018. CC BY 4.0 License.

\section{Natural Hazards and Earth System \\ Sciences \\ Discussions}

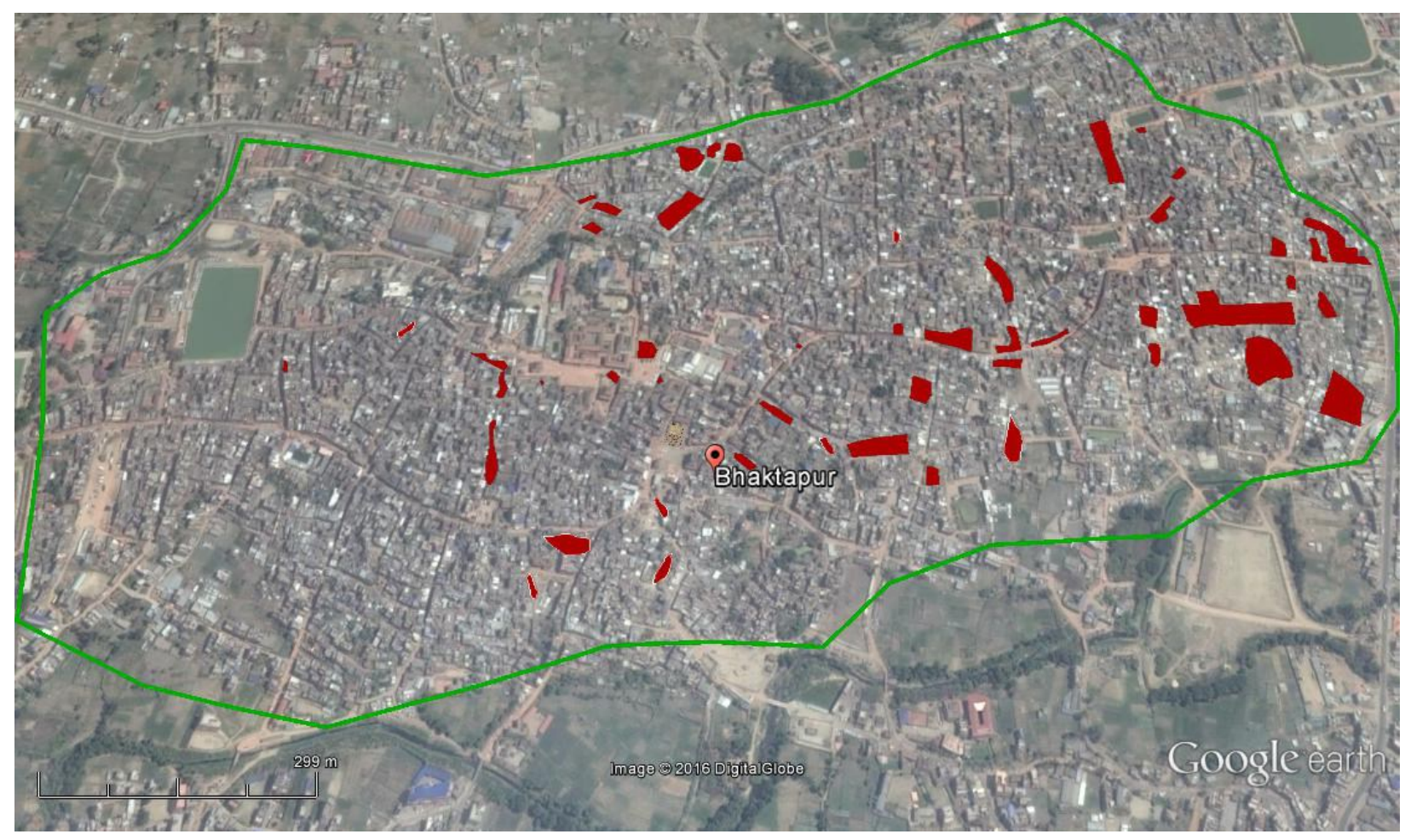

Figure 12: Major building collapse areas within the ancient settlement of Bhaktapur city (modified from: https://www.google.com/earth/). 
Nat. Hazards Earth Syst. Sci. Discuss., https://doi.org/10.5194/nhess-2017-435 Manuscript under review for journal Nat. Hazards Earth Syst. Sci.

Discussion started: 15 January 2018

(c) Author(s) 2018. CC BY 4.0 License.

\section{(c)}
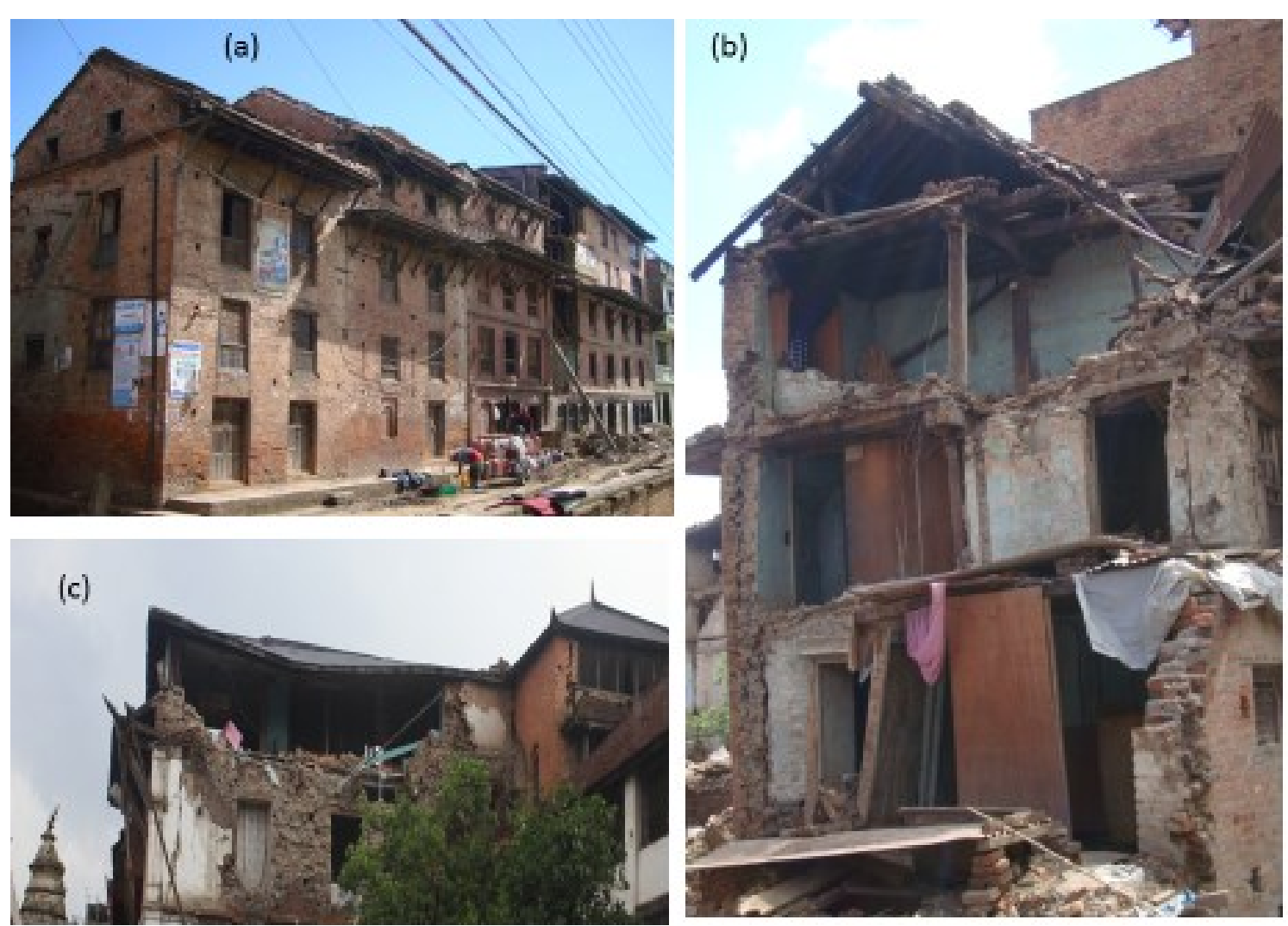

Figure 13: (a) Minor damage on roof (b) out of plane collapse of walls (c) gable collapse occurred due to Gorkha earthquake sequence.

\section{Natural Hazards and Earth System Sciences \\ Discussions}

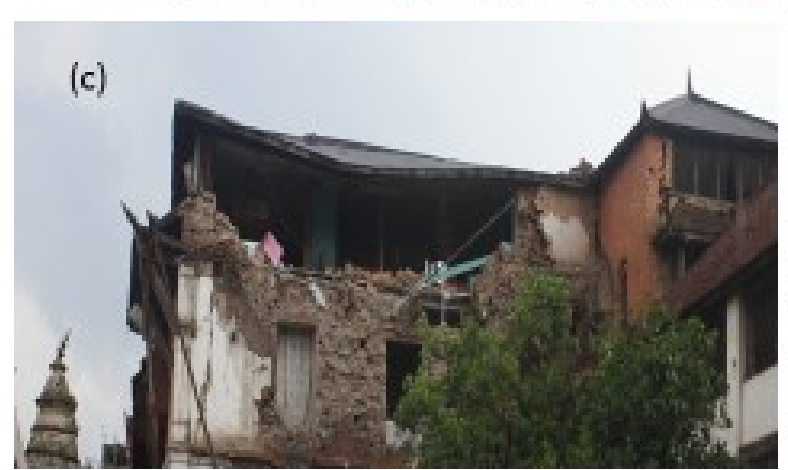


Nat. Hazards Earth Syst. Sci. Discuss., https://doi.org/10.5194/nhess-2017-435

Manuscript under review for journal Nat. Hazards Earth Syst. Sci.

Discussion started: 15 January 2018

(c) Author(s) 2018. CC BY 4.0 License.

\section{(c) (1)}

\section{Natural Hazards and Earth System \\ Sciences \\ Discussions}
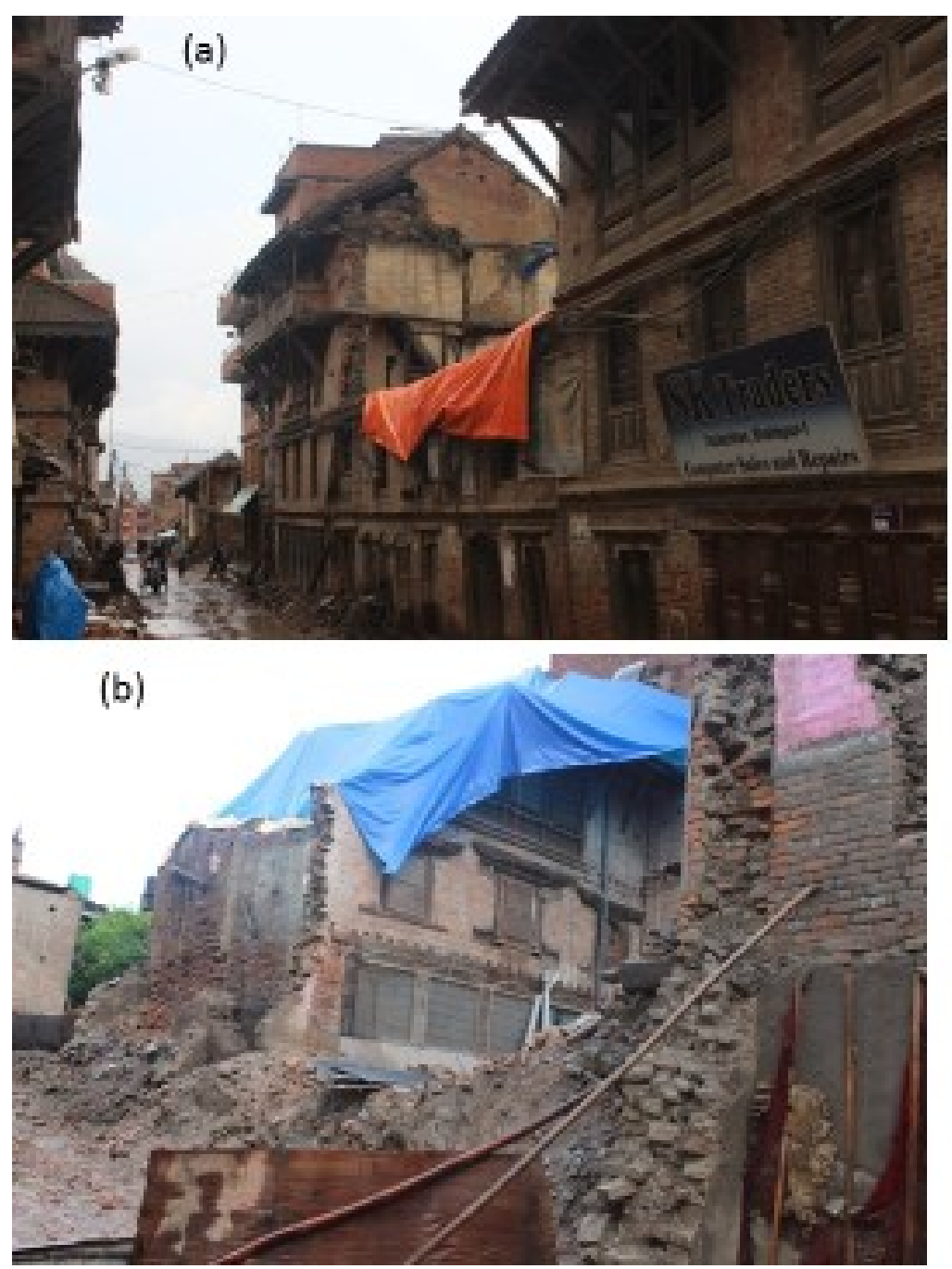

Figure 14: (a) Undamaged projections supported by cantilevered timber joists (b) collapsed wall on the building situated at the corner of row housing settlement due to Gorkha earthquake. 
Nat. Hazards Earth Syst. Sci. Discuss., https://doi.org/10.5194/nhess-2017-435

Manuscript under review for journal Nat. Hazards Earth Syst. Sci.

Discussion started: 15 January 2018

(c) Author(s) 2018. CC BY 4.0 License.

\section{Natural Hazards and Earth System \\ Sciences \\ Discussions}
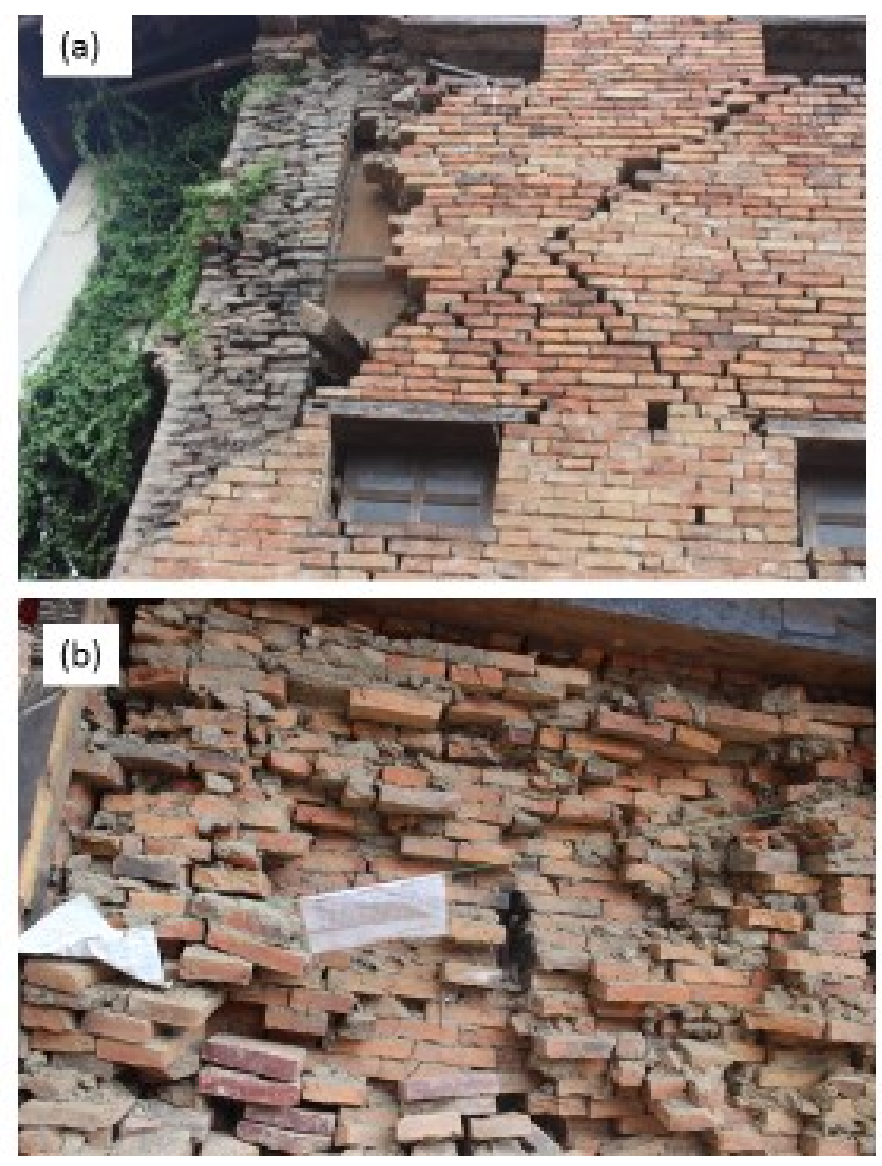

Figure 15: (a) Separation of orthogonal walls (b) delamination of wythes observed after the Gorkha earthquake. 
Nat. Hazards Earth Syst. Sci. Discuss., https://doi.org/10.5194/nhess-2017-435

Manuscript under review for journal Nat. Hazards Earth Syst. Sci.

Discussion started: 15 January 2018

(c) Author(s) 2018. CC BY 4.0 License.

\section{Natural Hazards and Earth System
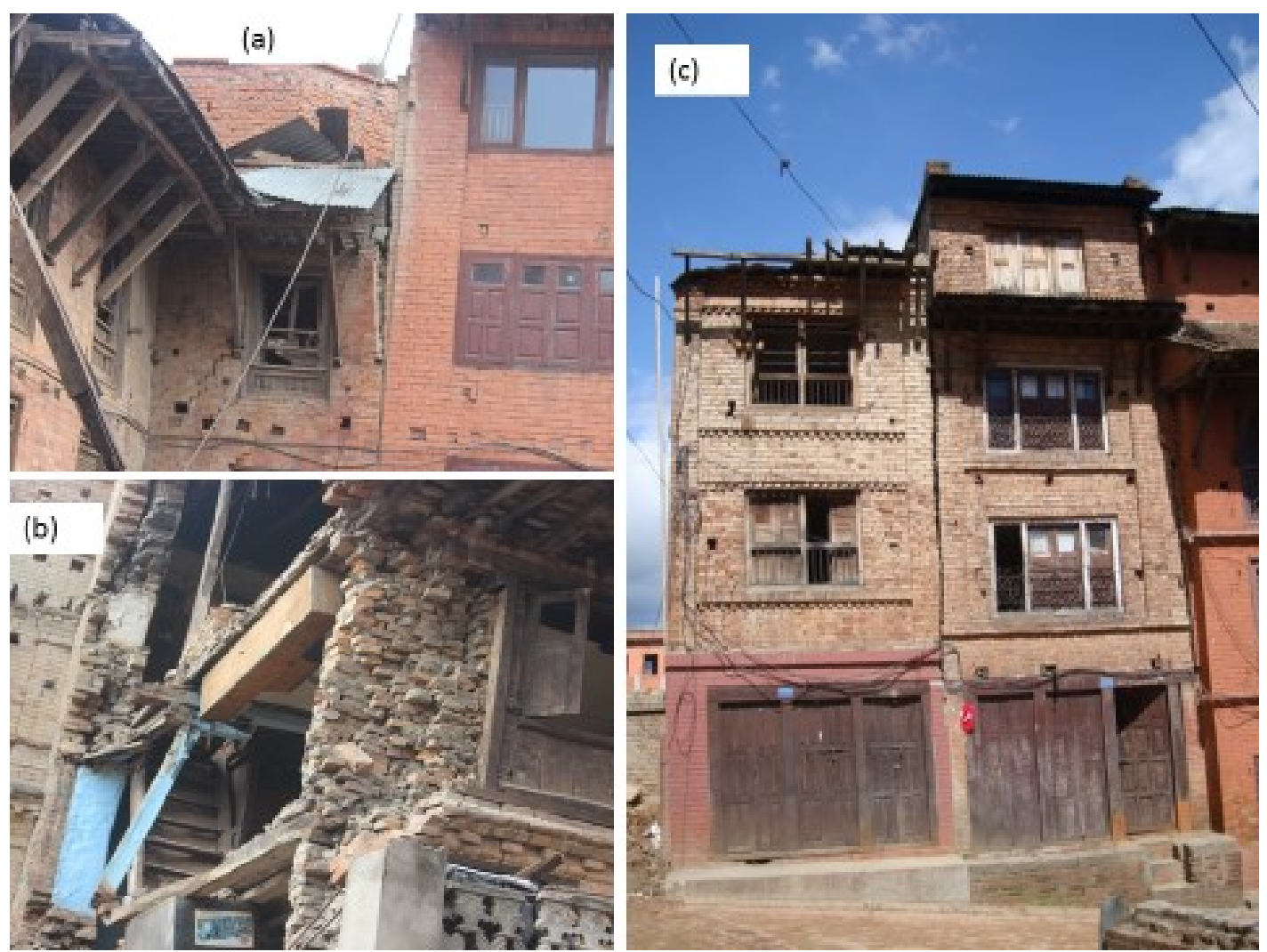

Figure 16: (a) Reentrant corner damage along with structural pounding (b) separated masonry units and the mud-mortar (c) structural pounding led separation due to variation in dynamic characteristic of jointed buildings observed during Gorkha earthquake. 
Nat. Hazards Earth Syst. Sci. Discuss., https://doi.org/10.5194/nhess-2017-435

Manuscript under review for journal Nat. Hazards Earth Syst. Sci.

Discussion started: 15 January 2018

(c) Author(s) 2018. CC BY 4.0 License.

\section{Natural Hazards and Earth System \\ Sciences \\ Discussions}
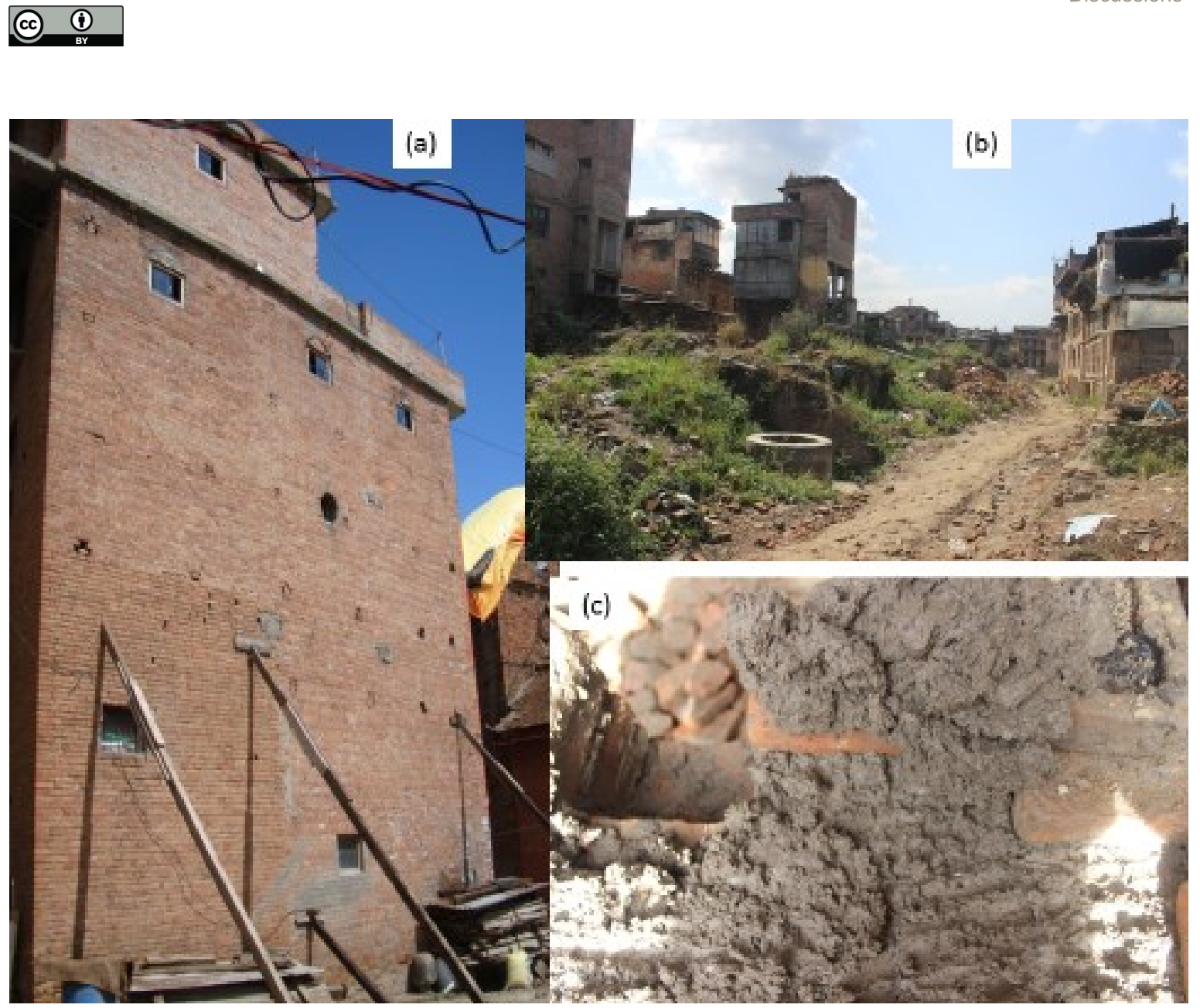

Figure 17: (a) RC slab constructed in pre-existing masonry building that underwent increment construction (b) destroyed neighborhood in Jenla ridgeline (c) mud mortar used for reconstruction after the earthquake. 
Nat. Hazards Earth Syst. Sci. Discuss., https://doi.org/10.5194/nhess-2017-435

Manuscript under review for journal Nat. Hazards Earth Syst. Sci.

Discussion started: 15 January 2018

(c) Author(s) 2018. CC BY 4.0 License.

\section{Natural Hazards and Earth System \\ Sciences \\ Discussions}

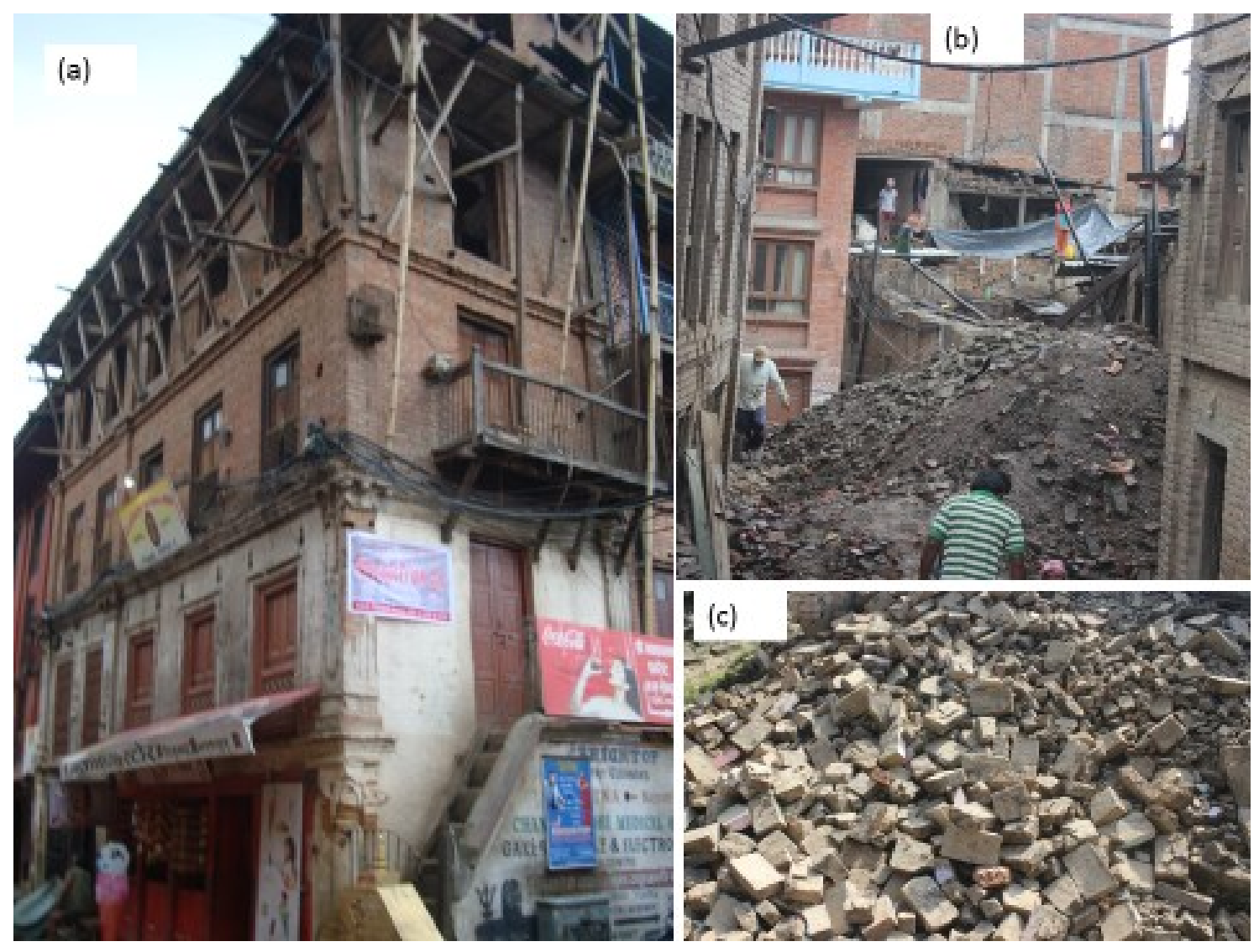

Figure 18: (a) Building with one masonry and next RC incremental construction above the vernacular masonry construction (b) debris reflects decay of construction material (c) irregular size and poor quality of bricks used for structural wall. 
Nat. Hazards Earth Syst. Sci. Discuss., https://doi.org/10.5194/nhess-2017-435 Manuscript under review for journal Nat. Hazards Earth Syst. Sci.

Discussion started: 15 January 2018

(c) Author(s) 2018. CC BY 4.0 License.

\section{Natural Hazards o and Earth System \\ Sciences \\ Discussions}
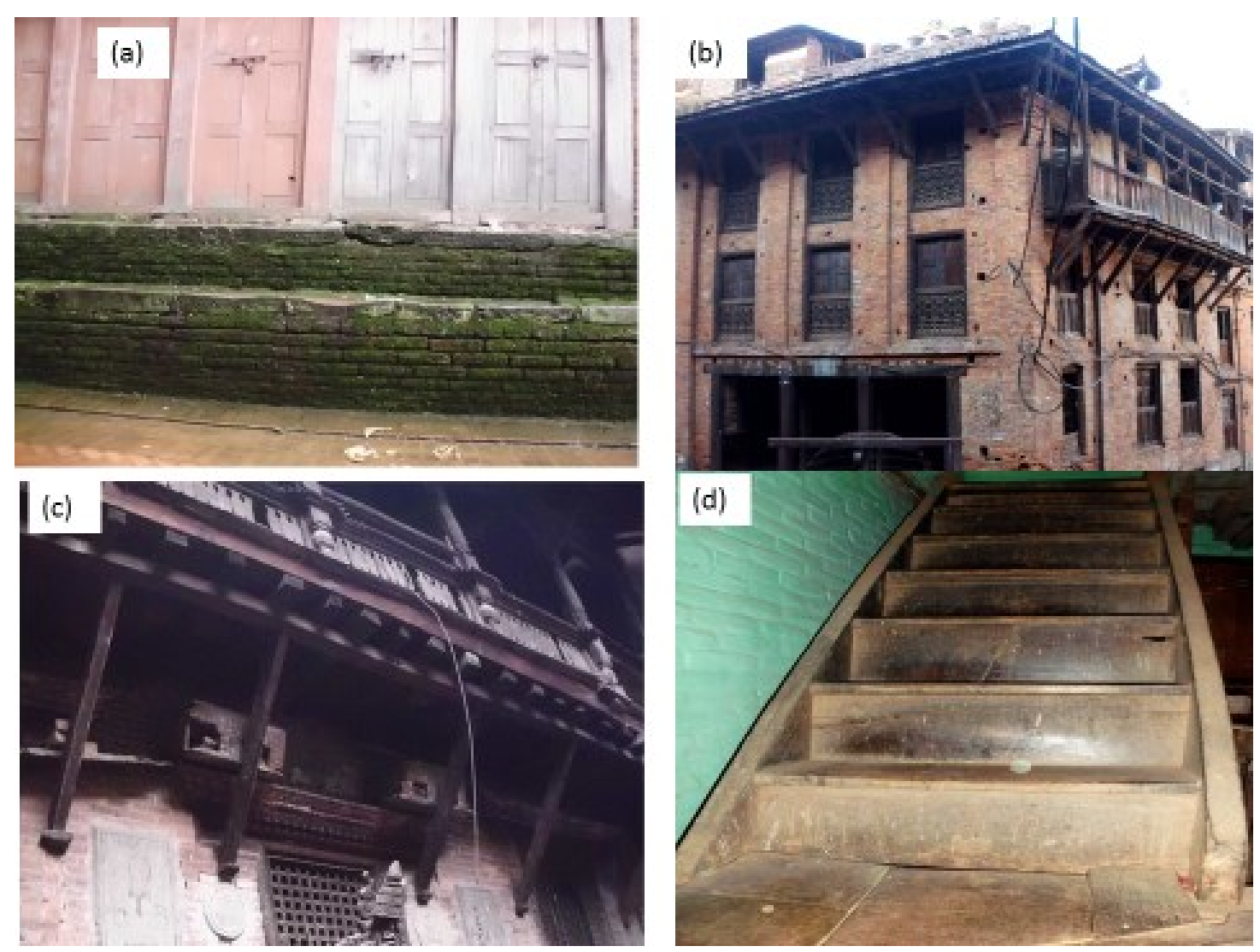

Figure 19: Identified seismic features: (a) plinth constructed in sloping ground (b) symmetrical building practice (c) timber struts for mainstreaming cantilevered load (d) wooden ladder. 
Nat. Hazards Earth Syst. Sci. Discuss., https://doi.org/10.5194/nhess-2017-435 Manuscript under review for journal Nat. Hazards Earth Syst. Sci.

Discussion started: 15 January 2018

(c) Author(s) 2018. CC BY 4.0 License.

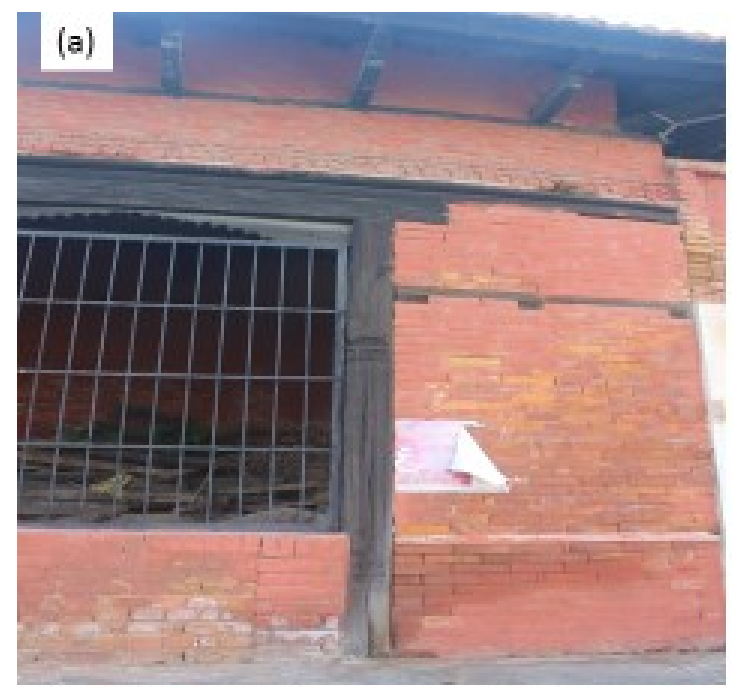

(b)

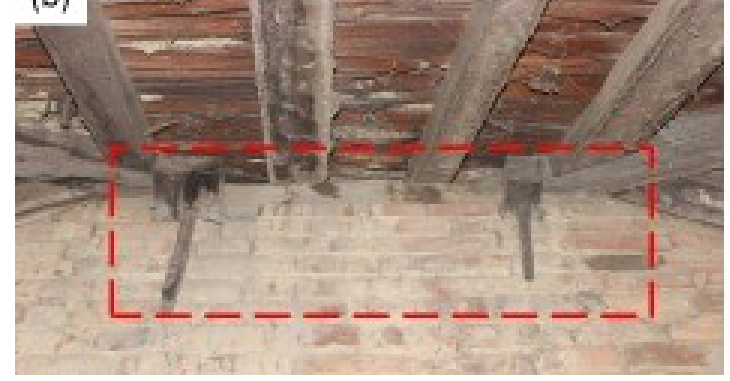

Figure 20: Identified seismic features: (a) timber bands at various levels (b) wooden pegs used to stitch connections (c) corner post.

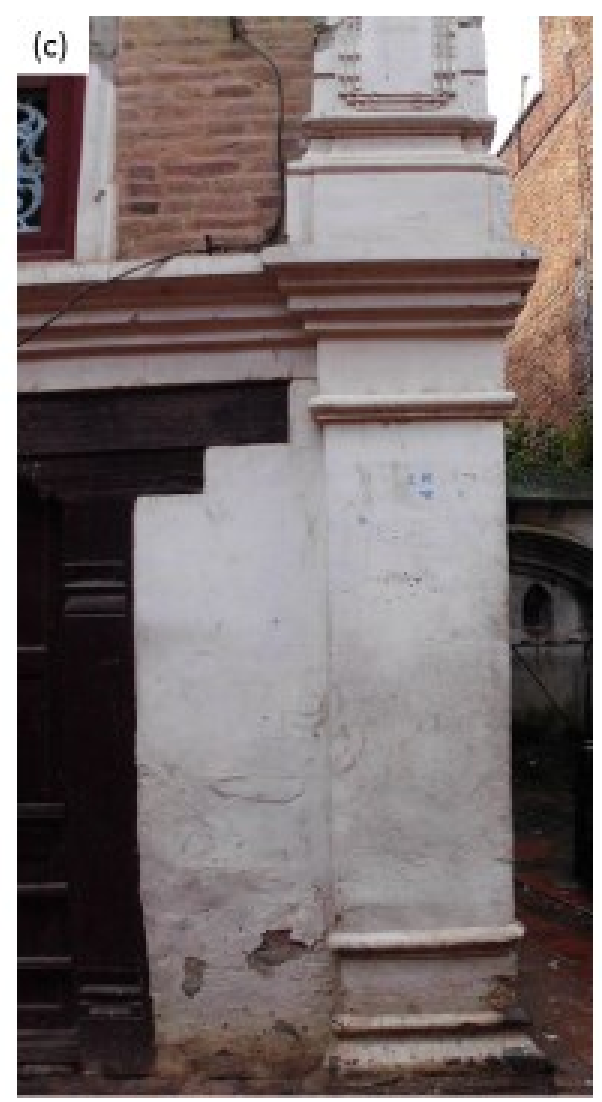

\section{Natural Hazards and Earth System Sciences \\ Discussions}


Nat. Hazards Earth Syst. Sci. Discuss., https://doi.org/10.5194/nhess-2017-435

Manuscript under review for journal Nat. Hazards Earth Syst. Sci.

Discussion started: 15 January 2018

(c) Author(s) 2018. CC BY 4.0 License.

(c) (i)

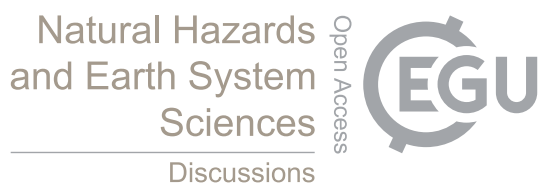

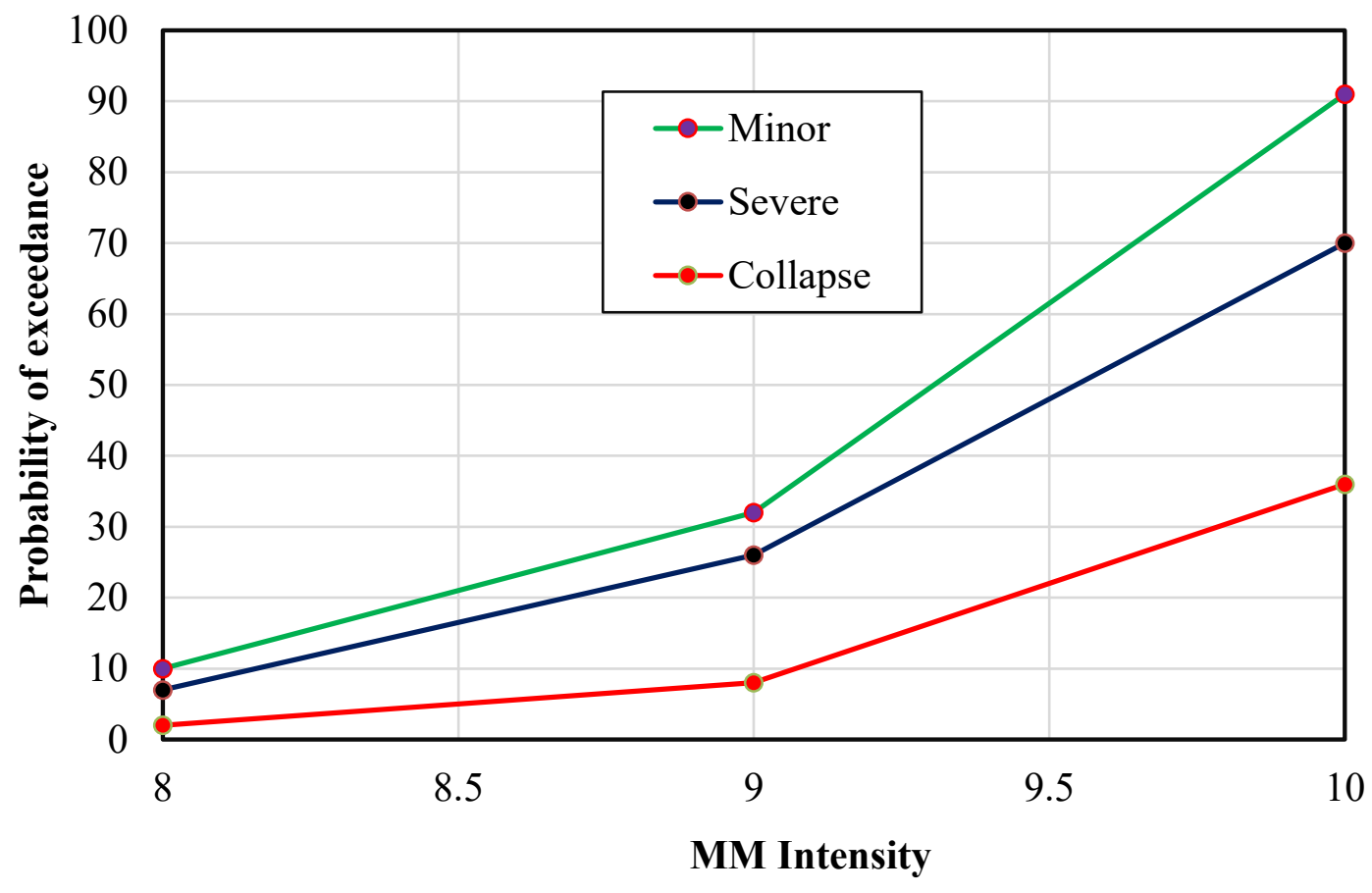

Figure 21: Fragility functions for traditional masonry buildings in Bhaktapur. 
Nat. Hazards Earth Syst. Sci. Discuss., https://doi.org/10.5194/nhess-2017-435

Manuscript under review for journal Nat. Hazards Earth Syst. Sci.

Discussion started: 15 January 2018

(c) Author(s) 2018. CC BY 4.0 License.

\section{(c) (i)}

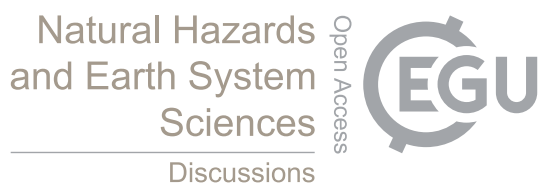

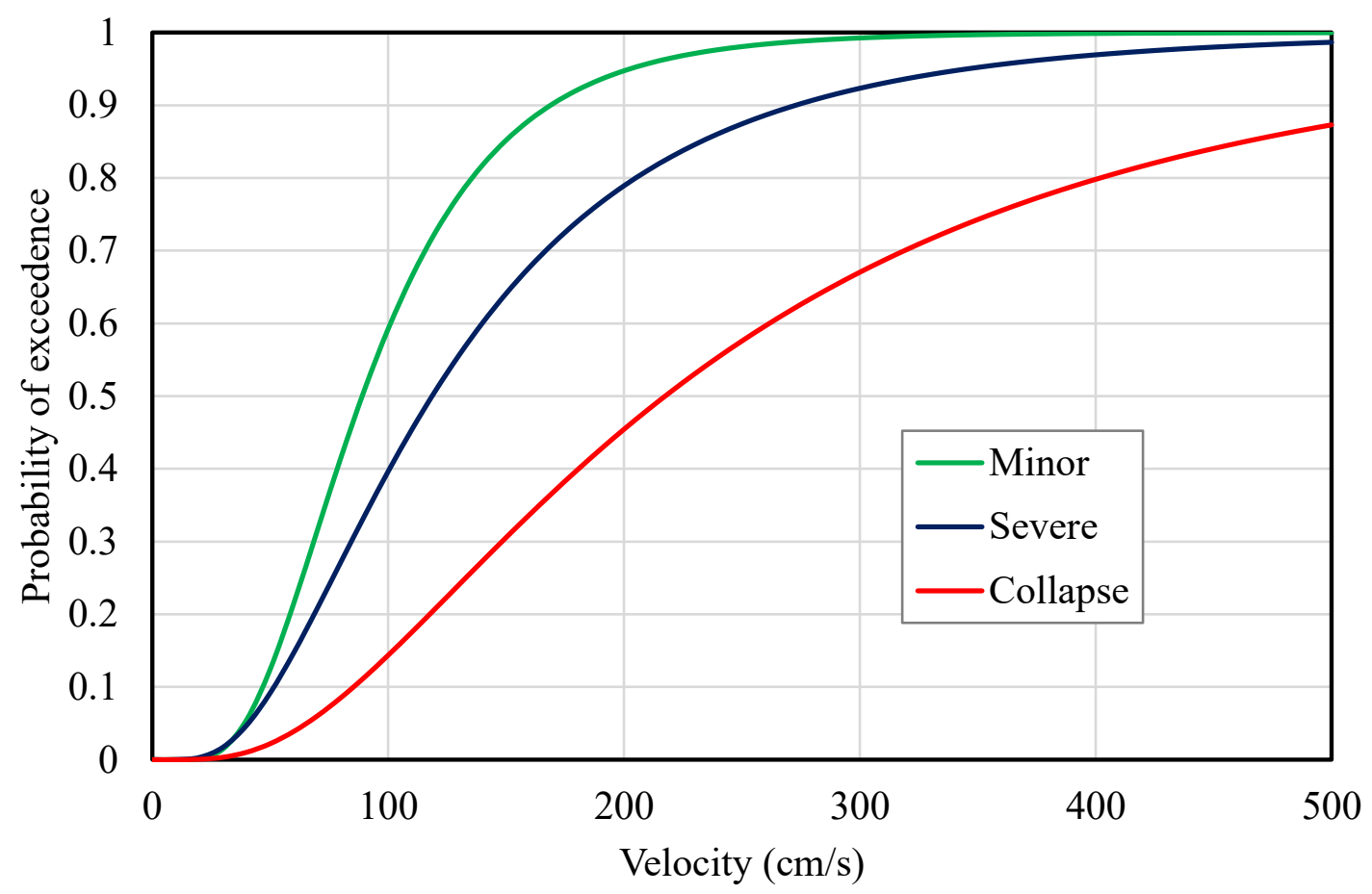

Figure 22: Fragility functions for traditional masonry buildings in Bhaktapur. 
Nat. Hazards Earth Syst. Sci. Discuss., https://doi.org/10.5194/nhess-2017-435

Manuscript under review for journal Nat. Hazards Earth Syst. Sci.

Discussion started: 15 January 2018

(c) Author(s) 2018. CC BY 4.0 License.

Table 1. Building element/aspect based damage scenario in Bhaktapur during Gorkha earthquake

\begin{tabular}{|c|c|}
\hline Damage element/aspect & Damage scenario \\
\hline Roof & $\begin{array}{l}\text { - Heavy roofs constructed using roof tiles were suffered in terms partial roof } \\
\text { collapse (Fig. 13a) } \\
\text { - } \quad \text { Galvanized iron sheets performed well }\end{array}$ \\
\hline Gable wall & 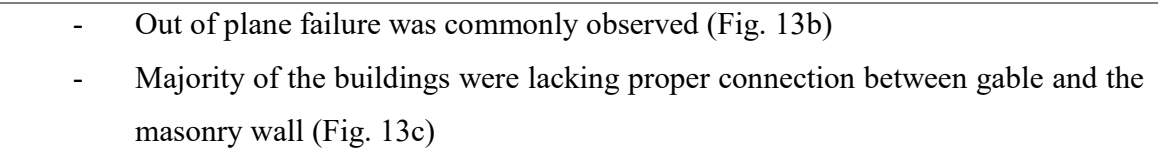 \\
\hline Projections & Wooden projections (various forms of windows) performed well (Fig. 14a) \\
\hline Wall & $\begin{array}{l}\text { - Out of plane failure was observed as the most prevalent failure mechanism (Fig. } \\
\text { 13c) } \\
\text { - Walls on the edge of the settlement suffered progressive collapse in out-of-plane } \\
\text { direction (Fig. 14b) } \\
\text { - } \quad \text { Out of plane collapse of heavy wall constructed in upper stories (Fig. 13c) } \\
\text { - } \quad \text { Walls were separated due to lack of proper connection and binding between } \\
\text { orthogonal walls as well as the structural and partition walls (Fig. 15a) } \\
\text { - } \quad \text { Feneered partition walls performed better than the heavy brick masonry partitions } \\
\text { openings and relatively larger in size } \\
\text { Delamination of wythes was observed in some cases (Fig. 15b) }\end{array}$ \\
\hline Corner & 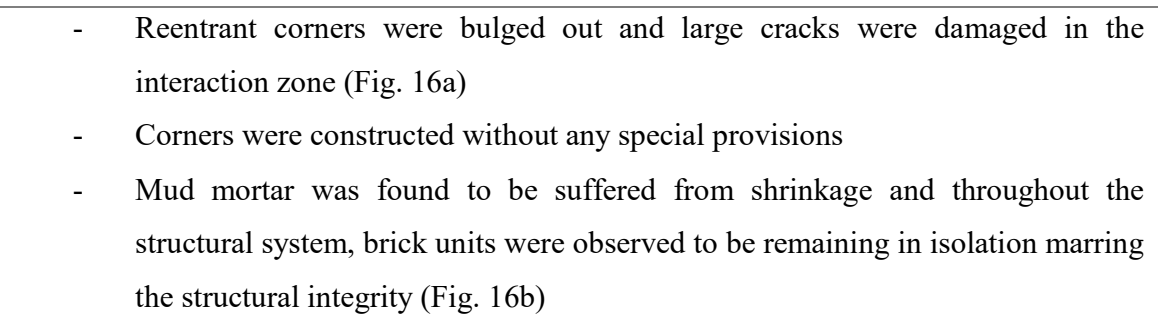 \\
\hline Structural pounding & $\begin{array}{l}\text { - Due to row housing system and intermediate modifications (reconstruction) and } \\
\text { due to high variation in dynamic properties of adjoining structures, many cases } \\
\text { of structural pounding led damaged were observed (Fig. 16c) } \\
\text { - Sometimes single building was found to be separated exactly into two halves and } \\
\text { partial reconstruction done, leading to damage in the remaining portion of } \\
\text { building. Change in slenderness ratio due to division of single building was also } \\
\text { observed in many buildings. }\end{array}$ \\
\hline Ground floor & $\begin{array}{l}\text { For commercial purpose, usually ground floor was not found to be provided with } \\
\text { structural wall rather shutters (wooden/iron) were prevalent and such buildings } \\
\text { with more height were observed to be damaged (Fig. 16c) }\end{array}$ \\
\hline
\end{tabular}


Nat. Hazards Earth Syst. Sci. Discuss., https://doi.org/10.5194/nhess-2017-435

Manuscript under review for journal Nat. Hazards Earth Syst. Sci.

Discussion started: 15 January 2018

(c) Author(s) 2018. CC BY 4.0 License.

(c) (i)

Natural Hazards

and Earth System

Sciences

Discussions

\begin{tabular}{|c|c|c|}
\hline RC slabs over masonry walls & - & $\begin{array}{l}\text { Such erroneous practice was observed in significant number of structures and the } \\
\text { collapse do RC slab led severe damage either in terms of brittle collapse or heavy } \\
\text { damage in entire structure (Fig. 17a) }\end{array}$ \\
\hline Construction site & - & $\begin{array}{l}\text { Areas like Suryamadhi, Inacho, Golmadhi, Byasi, Jela were more affected due to } \\
\text { inclined terrain and in some cases, due to ridgeline effect. A tow rows of more } \\
\text { than } 100 \text { buildings were destroyed in Jenla (Fig. 17b) and beside the Suryamadhi } \\
\text { square and Byasi all buildings except few RC were collapsed }\end{array}$ \\
\hline Mortar & - & $\begin{array}{l}\text { Even after the earthquake, mud mortar was being used (Fig. 17c) for } \\
\text { reconstruction and almost } 60 \% \text { buildings were constructed with mud mortar that } \\
\text { led to either collapse or heavy damage }\end{array}$ \\
\hline Incremental construction & - & $\begin{array}{l}\text { Many cases of incremental constructions were identified and surprisingly one or } \\
\text { two stories of substandard reinforced concrete construction were found (Fig. 18a). } \\
\text { Even in partly damaged buildings, after three months of the earthquake some } \\
\text { stories of RC were found to be added }\end{array}$ \\
\hline $\begin{array}{l}\text { Building age and occupancy } \\
\text { scenario }\end{array}$ & - & $\begin{array}{l}\text { Many of the damaged buildings were told be used for at least three generations } \\
\text { without any periodic strengthening even after the earthquakes during } 1988 \text { and } \\
2011 \text {, the debris from collapsed buildings was observed to be decayed (Fig. 18b) } \\
\text { Countable fraction of buildings of age more than } 82 \text { that sustained the } 1934 \text { Bihar- } \\
\text { Nepal earthquake were identified during field reconnaissance }\end{array}$ \\
\hline Masonry units & - & $\begin{array}{l}\text { Virtually all collapsed and heavily damaged structures manifested the marginal } \\
\text { quality of brick- improperly dried and irregular shape (Fig. 18c) }\end{array}$ \\
\hline
\end{tabular}


Nat. Hazards Earth Syst. Sci. Discuss., https://doi.org/10.5194/nhess-2017-435

Manuscript under review for journal Nat. Hazards Earth Syst. Sci.

Discussion started: 15 January 2018

(c) Author(s) 2018. CC BY 4.0 License.

(c) (i)

Natural Hazards

and Earth System

Sciences

Discussions

Table 2. Identified seismic features in vernacular Newari buildings

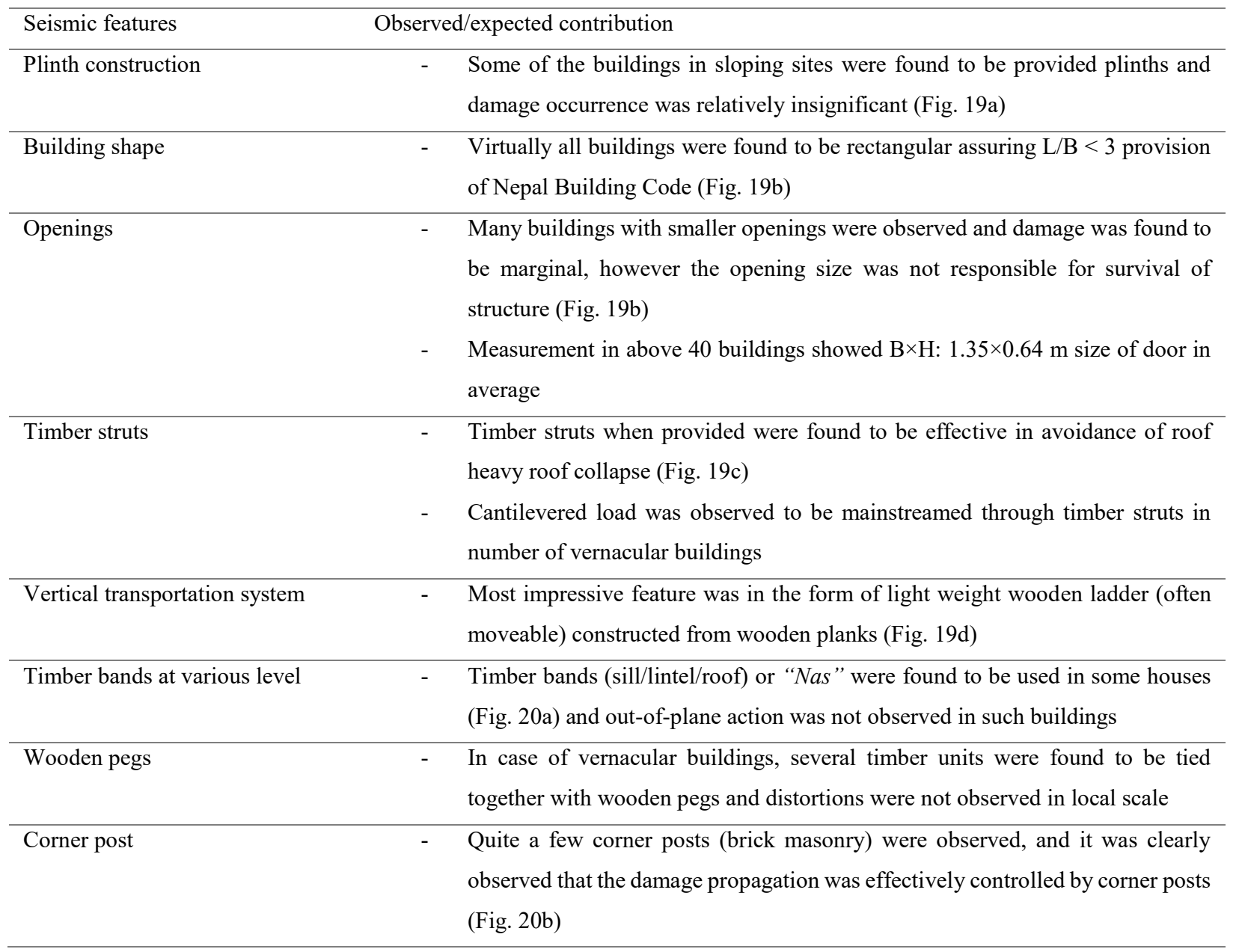


Nat. Hazards Earth Syst. Sci. Discuss., https://doi.org/10.5194/nhess-2017-435

Manuscript under review for journal Nat. Hazards Earth Syst. Sci.

Discussion started: 15 January 2018

(c) Author(s) 2018. CC BY 4.0 License.

(c) (1)

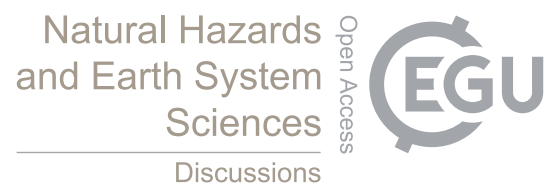

Table 3. DPMs for traditional masonry structures

\begin{tabular}{lllll}
\hline Damage state & Damage factor range & \multicolumn{2}{l}{$\begin{array}{l}\text { Probability }[P(D S, I)] \text { of being in each damage state as a function of } \\
\text { Modified Mercalli Intensity }\end{array}$} \\
\cline { 2 - 5 } & & MMI-VIII & MMI-IX & MMI-X \\
\hline No to slight damage & $0-5$ & 90 & 68 & 21 \\
\hline Minor damage & $5-30$ & 3 & 18 & 34 \\
\hline Severe damage & $30-70$ & 5 & 8 & 36 \\
\hline Collapse (local/global) & $70-100$ & 2 & 18.55 & 51.50 \\
\hline Mean damage ratio (MDR) & & 6.98 & 25322 & 6651 \\
\hline Total buildings & 10890 & & \\
\hline
\end{tabular}


Nat. Hazards Earth Syst. Sci. Discuss., https://doi.org/10.5194/nhess-2017-435

Manuscript under review for journal Nat. Hazards Earth Syst. Sci.

Discussion started: 15 January 2018

(c) Author(s) 2018. CC BY 4.0 License.

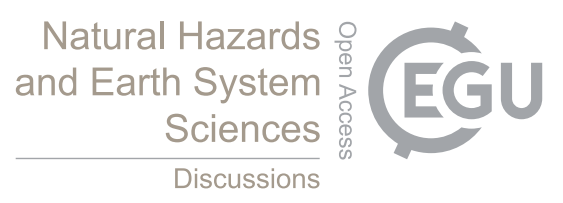

(c) (i)

Table 4. Summary of lognormal distribution parameters 